\title{
Marine Biofouling: A European Database for the Marine Renewable Energy Sector
}

\author{
Pedro Almeida Vinagre ${ }^{1, *}$ (D) Teresa Simas ${ }^{1}$, Erica Cruz ${ }^{1}$, Emiliano Pinori ${ }^{2}$ and Johan Svenson ${ }^{2,3}$ (D) \\ 1 Department of Marine Environment and Public Policies, WavEC Offshore Renewables, \\ 1350-352 Lisbon, Portugal; teresa@wavec.org (T.S.); erica.cruz@wavec.org (E.C.) \\ 2 Department of Chemistry, Biomaterial \& Textile, RISE Research Institutes of Sweden, 50462 Borås, Sweden; \\ emiliano.pinori@ri.se (E.P.); johan.svenson@cawthron.org.nz (J.S.) \\ 3 Cawthron Institute, 7010 Nelson, New Zealand \\ * Correspondence: pedro.vinagre@wavec.org; Tel.: +351-21-848-2655
}

Received: 3 June 2020; Accepted: 3 July 2020; Published: 5 July 2020

check for updates

\begin{abstract}
Biofouling is a major problem shared among all maritime sectors employing submerged structures where it leads to substantially increased costs and lowered operational lifespans if poorly addressed. Insight into the ongoing processes at the relevant marine locations is key to effective management of biofouling. Of specific concern for the marine renewable energy (MRE) sector is the fact that information on biofouling composition and magnitude across geographies is dispersed throughout published papers and consulting reports. To enable rapid access to relevant key biofouling events the present work describes a European biofouling database to support the MRE sector and other maritime industries. The database compiles in one document qualitative and quantitative data for challenging biofouling groups, including non-native species associated with MRE and related marine equipment, in different European Ecoregions. It provides information on the occurrence of fouling species and data on key biofouling parameters, such as biofouling thickness and weight. The database aims to aid the MRE sector and offshore industries in understanding which biofouling communities their devices are more susceptible to at a given site, to facilitate informed decisions. In addition, the biofouling mapping is useful for the development of biosecurity risk management plans as well as academic research.
\end{abstract}

Keywords: biofouling; colonization; macrofouling; mapping; marine renewable energy; maritime; non-native species

\section{Introduction}

Marine biofouling, the settlement of organisms on marine man-made structures, generate various and extensive challenges for industries developing technologies and working in the marine environment worldwide. Many of those industries, for example the diverse marine renewable energy (MRE) sector including offshore wind and ocean energy (such as wave and tidal) technologies, include marine installations and submerged equipment of ranging size and shape which are deployed at sea for long periods of time. For those, biofouling is a key challenge to overcome for the equipment to maintain a long and efficient operational lifespan [1,2].

A major economic impact of biofouling to the MRE relates to loss of structural integrity and performance caused, for example, by the added weight and thickness/rugosity to devices and components and obstruction of sensors. Key macrofouling organisms, such as acorn barnacles, mussels, calcareous tubeworms, bryozoans and kelp, are those most frequently referred in the literature as responsible for those impacts [3-5]. Other major economic impacts to the MRE relate to corrosion promoted by microfouling and macrofouling organisms. Corrosion may be induced and/or accelerated 
by anaerobic marine microorganisms via so-called microbiologically influenced corrosion (MIC) $[6,7]$. Macrofouling may further facilitate MIC initiated by the microbial communities that grow under the macrofoulers in oxygen-depleted conditions. Furthermore, some macrofoulers may promote localized corrosion as they employ endogenous compounds to adhere to (e.g., acorn barnacles) or perforate (e.g., boring bivalves) substrata [8,9]. Corrosion may be further accelerated if the coating of fouled devices is physically damaged by the attached organisms, for example when exposed to the pulling forces of waves and currents or upon their removal during maintenance.

To offer new and improved antifouling protection for the MRE sector, the European OCEANIC project (OCEANERA/0005/2014; http://oceanic-project.eu) was launched. OCEANIC aimed at developing a long-lasting (>10 years), "one-fit all", protection system against both biofouling and corrosion for the MRE sector. By combining two different strategies, the low emission antifouling (LEAF) approach developed by Pinori and co-workers $[10,11]$ and thermally sprayed aluminum (TSA), it was projected to produce an antifouling solution which was efficient and both economically and environmentally sustainable. While much of the OCEANIC project was based on technological developments, a specific output was the development of a European biofouling database/mapping, which is presented in this paper.

The database includes qualitative and quantitative data on species belonging to the five biofouling groups mentioned above-acorn barnacles, mussels, calcareous tubeworms, bryozoans and kelp-together with other relevant organisms such as hard-shelled organisms and gooseneck barnacles. It provides information about the occurrence of the organisms on MRE equipment and other structures, such as from the oil and gas sector, deliberate artificial reefs and test panels. It further contains information such as location coordinates, distance from land, water and wave height conditions of the sampled sites and the type of equipment and depth sampled. In addition, key biofouling parameters to the MRE sector such as biofouling thickness and weight are included.

Such a readily available database aims to provide to the developers, operators, regulators and researchers a quick overview of geographical biofouling distribution to facilitate informed decisions and help planning their projects, for example with site selection and subsequent probable frequency of maintenance. The mapping is useful in predicting the development of non-native species (NNS) populations [12] and, therefore, supports the development of biosecurity risk assessment/management plans to prevent the establishment and spread of NNS as a condition of their projects.

This paper is structured into two sections. Section 2 provides a brief review of important aspects regarding biofouling. It describes the colonization process and some of the factors influencing biofouling composition and abundance. Furthermore, an overview of key biofouling groups to the MRE sector and their impacts on equipment, biofouling control strategies, environmental issues and legislation applicable is included. Section 3 describes the design, development and status of the European biofouling database. It presents the database main findings and a summary of the data encompassed in it and thus provides the reader with an overview of what information is available and how to access it.

\section{Review of Biofouling Aspects}

\subsection{Colonization of Artificial Substrata}

Biofouling is a complex process that involves colonization by microfouling organisms, such as viruses, bacteria, cyanobacteria, fungi, protozoa and microalgae, and larger macrofouling organisms, including macroinvertebrates and macroalgae [13]. Macrofouling comprises calcareous hard-fouling organisms such as acorn barnacles, mussels and tubeworms and soft-fouling organisms such as non-calcareous algae, sponges, anemones, tunicates and hydroids.

The colonization process is often broadly described as a succession of four main stages, as shown in Figure 1a [13-15]: 
- Within minutes to hours of submersion, the substrata adsorb a biochemical conditioning biofilm, consisting of organic material such as glycoproteins, proteoglycans and polysaccharides naturally dissolved in the seawater.

- Within hours, primary colonizers, assemblages of unicellular organisms that secrete extracellular polymeric substances (EPS) adhere to the substrata. Together, the microorganisms and EPS facilitate the settlement of macrofoulers.

- Within days to weeks, secondary colonizers consisting of sessile macrofoulers, including softand hard-foulers, develop and overgrow the microfouling. As they grow and age, macrofoulers provide "micro-habitats" that attract further settlements.

- Within weeks to months, the substrata are fouled by tertiary colonizers which typically reside within the sessile biofouling. The biofouling communities reach maturity within a few years, accompanied by an increase in species diversity and richness. The communities are characterized by a variety of sessile and mobile benthic and epibenthic organisms.

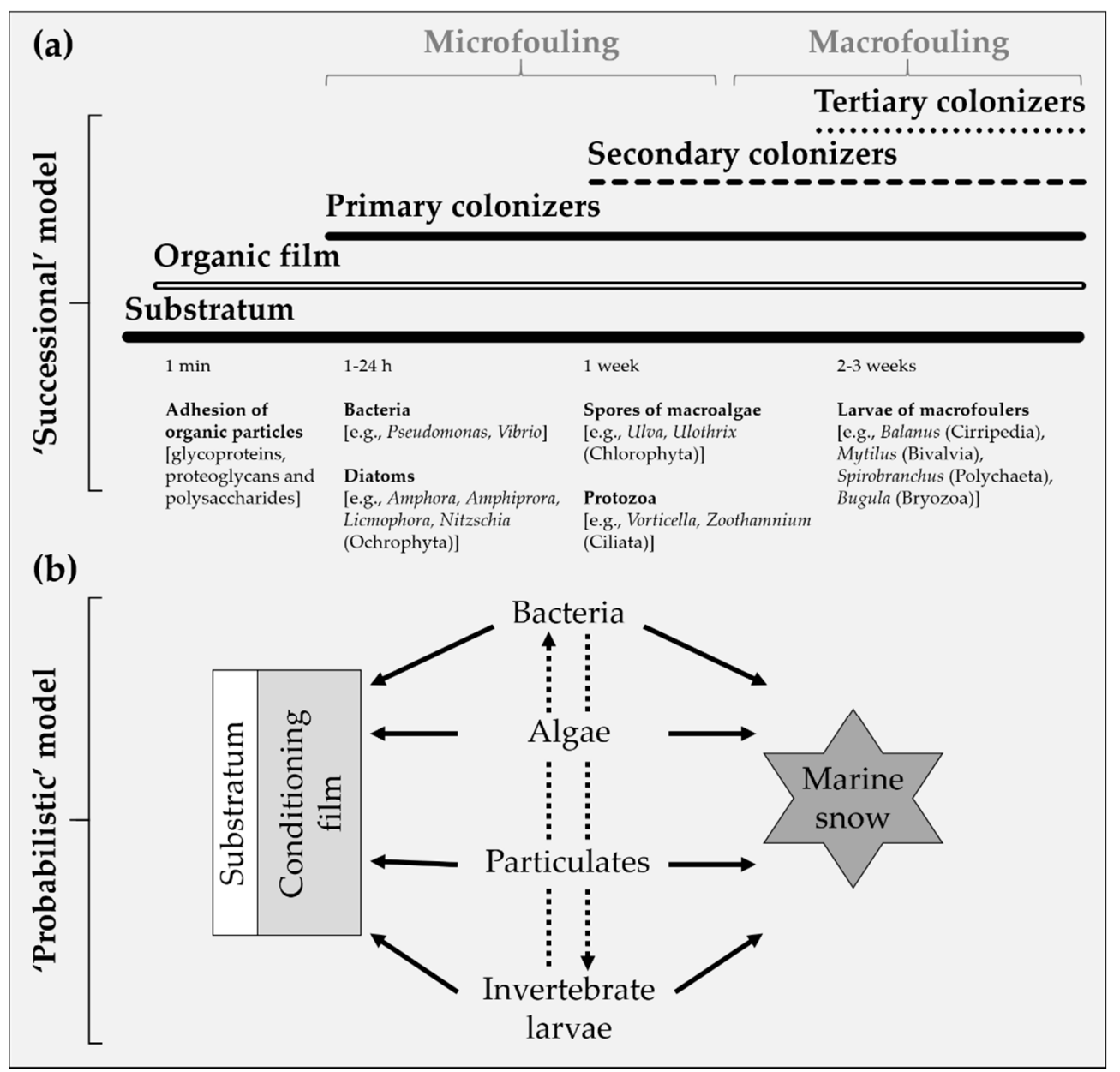

Figure 1. Schematic models of marine biofouling colonization: (a) "successional" model (after [13,14]); and (b) "probabilistic" model (after [16,17]).

While this classic "successional" model may represent major patterns of biofouling development, it oversimplifies the colonization process as implying causality from stage to stage. It is now widely accepted that colonization follows a more dynamic and "probabilistic" model (Figure 1b), in which the absence of a stage does not impede the occurrence of another stage. For example, some acorn barnacle and bryozoan species may settle on a substratum without the presence of a conditioning biofilm [18]. Colonization is thus greatly dependent on the type and number of organisms, whose settlement is 
independent of one another, that could attach to or colonize the substratum $[16,17,19]$. In the absence of a substratum, foulants may aggregate and form marine snow [16], which remains in seawater and may eventually attach to a substratum. Living organisms such as invertebrate larvae and algal spores trapped in the marine snow grow after attachment [20].

\subsection{Factors Influencing Marine Biofouling}

The composition of biofouling communities varies greatly geographically, seasonally and locally across depths or in different levels of wave exposure and is influenced by numerous abiotic and biotic factors [13]. The abiotic factors include the physical-chemical characteristics of seawater, such as temperature, $\mathrm{pH}$, dissolved oxygen and organic matter content. In addition to those factors, abiotic factors include hydrodynamic conditions such as current velocity, wave exposure, distance to shore and depth. Substratum features such as the material composition (for example, metal vs. plastic), color, roughness, period of submersion and motion (for example, free moving equipment such as tidal turbines vs. static structures such as foundations) also influence settlement and growth [21-23]. Among biotic factors, the biology of the different organisms will dictate how likely a settlement is on a submerged substratum. This, in turn, depends on many species-specific interactions and can differ greatly from species to species in different locations. In addition, chemical cues released in response to competition, reproduction, grazing and predation also play a big role in the settlement and surface recruitment of different organisms [24-26]. Many of the factors are interrelated, and all are directly or indirectly affected by seasonality and location.

While the biofouling process evidently is complex and highly dependent on physical, geographical, and biological parameters, the current paper will focus on a selection of important abiotic factors.

\subsubsection{Seawater Temperature}

Seawater temperature is related to latitude and seasonality and is a major geographical determinant of the composition of marine communities, including biofouling composition, influencing the spawning period, settlement, growth and reproduction of organisms [27]. Generally, biofouling growth rate increases with temperature and therefore less biofouling is expected closer to Polar areas owing to the lower temperatures $\left(<5^{\circ} \mathrm{C}\right)$. In those regions, biofouling occurs typically during mid-summer when temperatures are higher. In contrast, in tropical to sub-tropical locations, biofouling is generally more intense since the warmer temperatures $\left(>20^{\circ} \mathrm{C}\right)$ allow continuous reproduction throughout the year, enabling an increased growth rate of the biofouling organisms. In temperate areas, with mild temperatures $\left(5-20^{\circ} \mathrm{C}\right)$, biofouling will occur throughout the year and show strong seasonality, with most spawning and growth occurring from spring (beginning of April) to early autumn (end of October) [21,28]. The temperature of the substrate where organisms grow have significantly less influence on the growth [29].

\subsubsection{Depth and Light Availability}

Depth and light availability greatly affect the composition and growth of biofouling organisms. Macrofoulers, especially photosynthetic organisms such as macroalgae, are usually more abundant in sections within the euphotic zone $(0-40 \mathrm{~m})$ [30]. This zone is generally warmer, presents higher light levels and is rich in plankton, which serve as the main food resource for many non-photosynthetic organisms. As a consequence of a decreased light intensity with depth, within this zone, the biofouling growth and biomass generally decrease with depth [21,29]. Despite the decrease in biofouling pressure with depth, the settlement of sessile, filter-feeding invertebrates such as acorn barnacles and mussels, which often constitute the bulk of macrofouling, occurs down to great depths [31].

\subsubsection{Currents and Distance to Shore}

Both the composition and extent of biofouling on a colonizable substratum are affected by currents and the distance from shore [29]. Many organisms such as mussels, barnacles and tubeworms benefit 
from currents as they feed on particles suspended in the water or on nutrients dissolved in the water [15]. The motile larvae of many invertebrates and the spores of algae are carried offshore by currents and, the closer is the substratum to the shore, the higher is the probability of colonization success, especially of fixed structures such as platforms [29]. The impact of currents and water flow on biofouling communities will depend on the velocities and shear forces that are generated near the substratum [32]. For example, while sessile filter-feeding organisms may benefit from high flows in terms of receiving particles as food resource, strong currents may dislodge organisms from the substratum. To cope with dislodgement when in the adult form, many sessile organisms such as barnacles have developed sophisticated mechanisms for strong surface adhesion [33-35]. On the other hand, lower flows may facilitate the settlement of larvae/spores of some organisms.

\subsubsection{Material of Substrata}

The different materials used as artificial substrata will dictate their reactivity and toxicity and, therefore, influence the biofouling susceptibility of the substrata. The physical-chemical properties of materials can affect the water chemistry and seawater-substratum interface chemistry, influencing the formation and nutrient composition of the macromolecular conditioning layer. These properties affect the bacteria present on the substratum, usually with greater diversity being associated with biologically and chemically inert substrata which are more stable, thus facilitating rapid macromolecular conditioning and subsequent biofilm formation [36]. This, in turn, may affect macrofouling settlement and growth. It has been reported that aluminum, carbon steel and bronze are more susceptible to biofouling than some non-metallic substrata such as glass fiber, polyethylene, polyamide and rubber $[1,37]$. Among metallic substrata, aluminum-based substrata appear to present much less biofouling compared to for example bronze- and Monel-based ones (Vinagre et al. 2019 unpublished data). However, the response of biofoulers to materials is not universal and different biofouling groups or different species within-group may display different responses to the same material depending on factors such as temperature and depth.

\subsubsection{Topography and Wettability of Substrata}

The topography of substrata influences the physical and environmental conditions offered to the organisms. Higher heterogeneity of the substratum will allow for different microhabitats by providing a larger surface area, which enables higher diversity and lower competition between species. The level of microtopography, roughness and texture may also influence the ability of organisms to adhere to that surface affecting, for example, biofilm accumulation and subsequently the biofouling extent [32,38-40]. Many algae have non-motile spores with low or no selectivity for substratum and to those the microtopography is important in physically restraining the spores and allowing them to adhere. Moreover, settlement of many invertebrate larvae is affected by microtopography, acting as cues assisting larval site selection [4,32]. Therefore, smoother surfaces are generally less susceptible to biofouling than rougher surfaces $[39,40]$.

The microtopography of a substratum affects its wettability, and this influences the adhesion of biofouling organisms as the wetting process determines the actual contact area and interaction force between the adhesive and the substratum. However, no unique relation can be established between the hydrodynamic characteristics of the surface and the adhesion strength of the organism. For example, while the adhesive strength of acorn barnacles seems to be greater on high wettability surfaces [18], different species appear to settle at a higher rate on hydrophobic substrata (Balanus improvisus) or hydrophilic substrata (B. amphitrite) [41].

\subsubsection{Color of Substrata}

The color of a substratum relates to the amount of energy reflected and absorbed by the substratum, as well as to the temperature of the substratum, which can be determinants of biofouling settlement [42]. It has been shown that the color of a substratum exerts a greater influence on the early stages of 
biofouling and is thus mainly a factor to consider for equipment that are submersed for short periods. Larvae and spores of many organisms show a negative phototaxis and prefer darker and less reflective substrata during settlement [41-43]. In addition, bacterial biofilms are affected by substratum color and could thus be important in dictating the subsequent biofoulers which may not be directly influenced by the substratum color [43-45]. Over time (months-years), as the biofouling communities become more complex, differences between darker and lighter substrata should become negligible [45].

\subsection{Key Macrofouling Groups to the MRE Sector}

Biofouling is complex and differs significantly depending on location and over 4000 different marine organisms have been associated with biofouling [22,46]. While the number of microfoulers can be very high on a substratum, the less diverse macrofouling organisms make up the bulk of the weight and/or hydrodynamic load and thickness. Five groups of macrofoulers have been identified as those causing the greatest impact to MRE structures deployed at sea via different mechanisms [3-5], namely: (i) kelp (soft-fouling); (ii) bryozoans (soft- to hard-fouling, depending on the species); (iii) mussels; (iv) acorn barnacles; and (v) calcareous tubeworms (hard-fouling). This section provides an overview of these groups in European waters, with their impact to the MRE sector being described in Section 2.4.

\subsubsection{Kelp (Phylum Ochrophyta, Class Phaeophyceae, Order Laminariales)}

\section{Overview}

Kelp (Figure 2) are large intertidal and subtidal brown algae of the Order Laminariales (e.g., Laminaria spp., Saccharina latissima and Saccorhiza polyschides) that often form large populations in temperate-cold seas (e.g., Northern Europe). Kelp are usually found from the tidal zone down to a depth of $30 \mathrm{~m}$ depending on light availability and exposure to waves and currents [47]. Some species can populate deeper waters [30] due to a high concentration of fucoxanthin, a pigment that allows them to use the blue part of the solar radiation spectrum [48]. European kelp has a lifespan of approximately 15 years and assemblages generally reach $5 \mathrm{~m}$ in length with the largest kelp in the world, Macrocystis pyrifera, reaching up to $50 \mathrm{~m}$ in length [48]. M. pyrifera is originally a South Pacific species but has been reported as an NNS worldwide including Europe, thus also representing a biofouler in European regions [49,50].

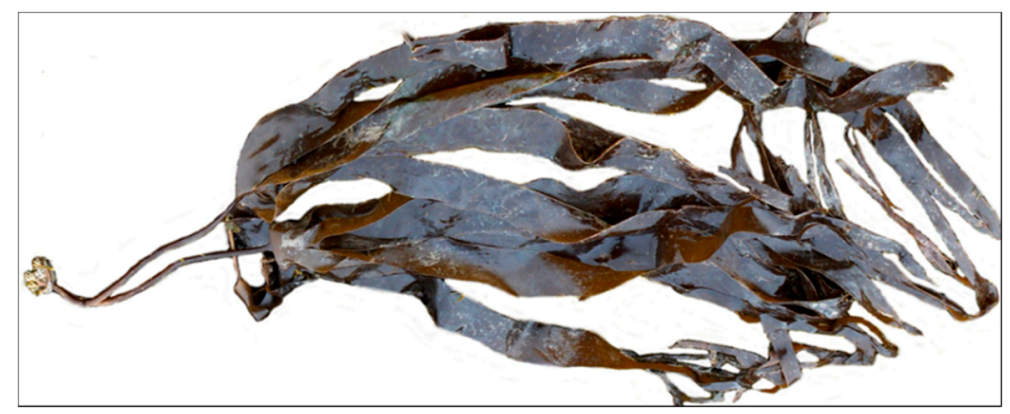

Figure 2. Kelp (Laminaria digitata; accessed at https://eol.org).

Life Cycle

The life cycle of the Laminariales displays a strong seasonality in most species $[30,48,50]$. Light, temperature and the photoperiod greatly influence growth, especially of the adult sporophyte, not only influencing the photosynthetic activity but also acting as a trigger for the regulation of seasonal growth [30]. In Europe, temperate-cold species grow at $0-20{ }^{\circ} \mathrm{C}$ while warm-temperate species can grow at up to $23-24^{\circ} \mathrm{C}$ [30]. In the North Sea, S. latissima and L. hyperborea grow in winter and early spring, while L. digitata grows from spring to the end of summer [30]. Fruitification generally takes place during periods of low or no growth. Therefore, many Laminaria commonly fruit from 
autumn to winter coinciding with decreasing light conditions and temperatures, and only a few species fruit mainly in summer. The motile spores (meiospores, 5-7 $\mu \mathrm{m}$ [15]) can be released over several months [30].

\subsubsection{Bryozoans (Phylum Bryozoa)}

\section{Overview}

The Phylum Bryozoa (Figure 3) includes three Classes-Stenolaemata, Gymnolaemata and Phylactolaemata. Bryozoans (moss animals) form characteristic dense colonies composed of numerous individual units-zooids-which act coordinated within the colonies. The colonies range in shape and form. Many "encrusting" to "bush-like" forms exist, which can be either calcareous or non-calcareous. Colony size is variable and ranges between millimeters to meters depending on the species [51]. Attachment to substrata is facilitated by strong underwater bioadhesives [52] and bryozoans may reach abyssal depths, depending on the species and its larval development mode [53].

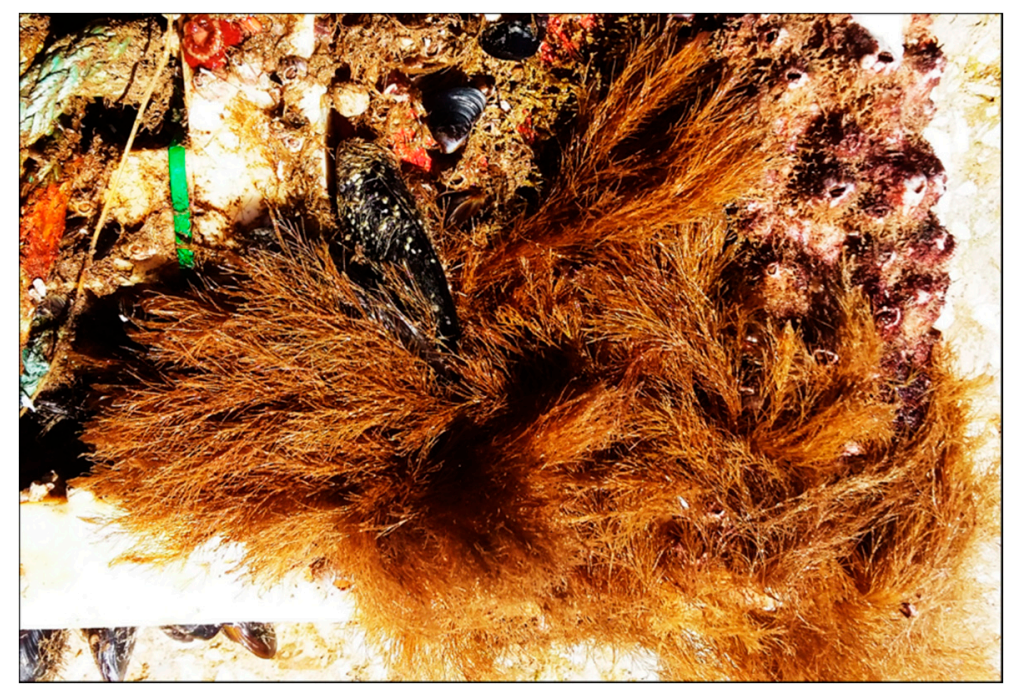

Figure 3. Bryozoans (cf. Bugula sp.) growing on test panels.

Life Cycle

The bryozoan colonies expand generally during summer via asexual budding which includes the formation of clones from the primary zooid or group of zooids which remain attached to the colony. In addition, as the colony matures, some zooids undergo gametogenesis, producing male spermatozoa and female eggs. Fertilized eggs develop into larvae (250-300 $\mu \mathrm{m}$ [51]) which metamorph into adults within a few hours after being released [53]. The lifespan of bryozoans is undefined since budding may occur continuously at different parts of the colony.

The larvae of most bryozoan species display positive phototaxis when released, generally becoming partially/totally photonegative at settlement $[15,51]$. Settlement on artificial substrata may be observed within $1 \mathrm{~h}$ to 1 day of submersing an artificial substratum [18] and it is often highly specific and strongly influenced by the chemical properties of the substratum. Settlement is generally more frequent on substrata with initially low critical surface energy [18]. Some species prefer to settle on biofilmed substrata (Bugula neritina and B. stolonifera), while others (B. flabellata and Celleporella hyalina) prefer substrata without established biofilms $[51,54,55]$. Furthermore, some larvae are able to detect the presence of mature individuals, allowing the selection of suitable substrata to settle [52]. 


\subsubsection{Mussels (Phylum Mollusca, Class Bivalvia, Family Mytilidae)}

\section{Overview}

Mussels (Figure 4) are dominant organisms in the intertidal to subtidal zones and they can survive in different and diverse marine ecosystems [56]. Mussels tolerate a wide range of environmental conditions, for example of salinity and water temperature, and display both great reproductive potential and fast growth $[57,58]$. Altogether, this allows mussels to be both a highly adaptive and potentially effective invasive organism. Many species of mussels grow up to over $100 \mathrm{~mm}$ and often live for more than 10 years, with some species having significantly longer lifespans [58,59]. Mussels frequently dominate marine growth on offshore structures in the upper $30 \mathrm{~m}$ of the water column $[56,60]$ but can live at least down to a depth of $100 \mathrm{~m}$ [57]. The two most common mussels associated with biofouling in European waters are the blue mussel (Mytilus edulis) and the Mediterranean mussel (M. galloprovincialis).

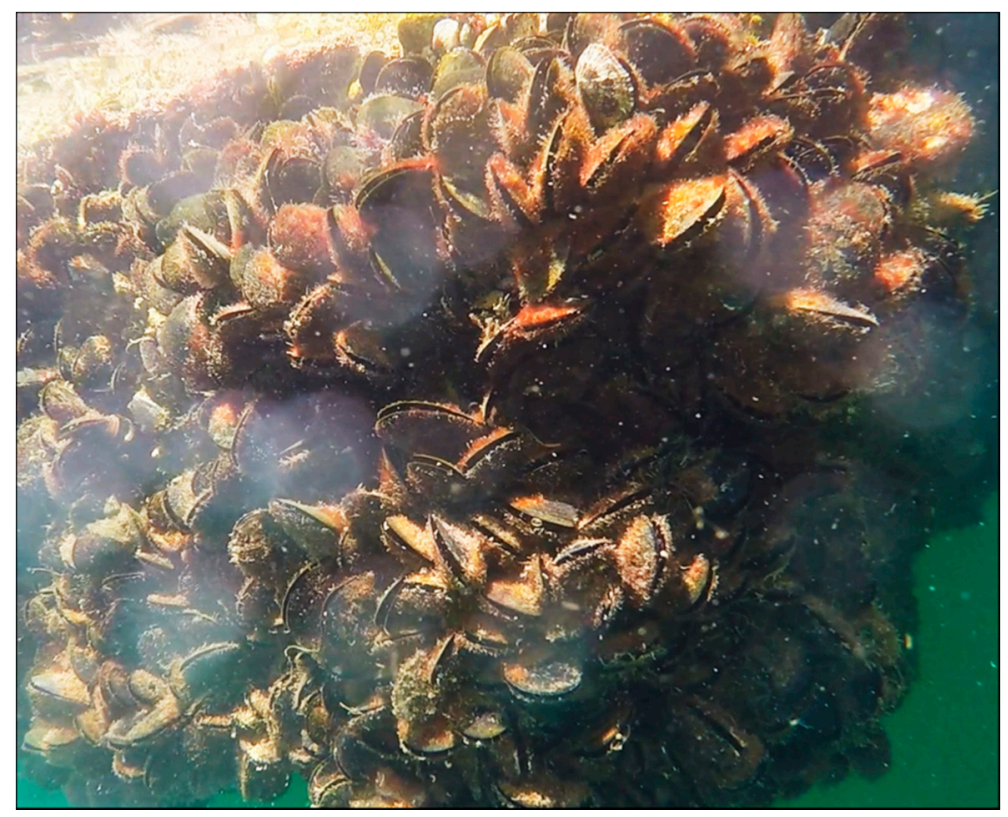

Figure 4. Dense assemblage of mussels (Mytilus galloprovincialis) growing under a marina walkway.

Life Cycle

Mussels reach reproductive maturity generally within 1-5 years, depending on factors such as water temperature, depth, currents and exposure. Breeding and broadcast-spawning may happen throughout the year but most often it occurs during spring to late summer [58]. The planktotrophic larvae of mussels $(250-300 \mu \mathrm{m})$ are motile and may persist in seawater for up to six weeks [58,59]. Larvae generally prefer to settle on rough, hydrophobic and/or biofilmed substrata or filamentous algae $[58,61]$. Settled larvae and juveniles are capable of voluntarily detaching from a substratum to find a suitable site to reattach $[15,55,61]$. After settlement, the larvae metamorph into adults.

\subsubsection{Acorn Barnacles (Phylum Arthropoda, Subphylum Crustacea, Infraclass Cirripedia)}

\section{Overview}

Barnacles are crustaceans from Infraclasses Ascothoracica and Cirripedia. Superorder Thoracica (Cirripedia) includes the most common barnacles, i.e., the gooseneck/stalked/pedunculate barnacles and acorn barnacles (Figure 5) [31]. Barnacles represent the only crustaceans living attached to substrata as sessile adults [31]. 


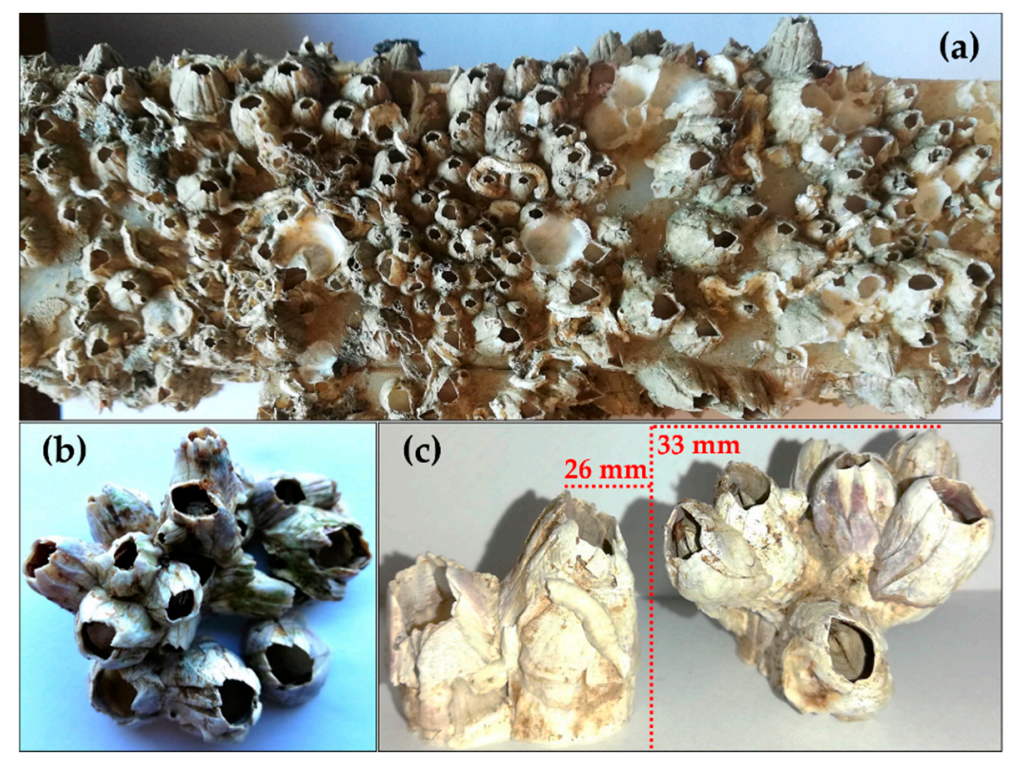

Figure 5. Acorn barnacles (Perforatus perforatus) growing on a nylon structure: (a) barnacles found on a marina walkway; (b) top view detail; and (c) side view detail, with an individual measuring $26 \mathrm{~mm}$ tall and a clump measuring $33 \mathrm{~mm}$ tall.

Barnacles (henceforth referring to acorn barnacles) constitute a potentially dominant macrofouling group in a variety of locations and pose a great threat to many marine structures [62]. Barnacles are greatly resistant to dislodgement by currents and waves as their adhesion strength is very high (0.02 MPa in juveniles to over 2.00 MPa in adults), although variable with substratum, species and age/size of individuals $[33,63,64]$. In European waters, barnacles are commonly found in the tidal and the sublittoral zones $(0-100 \mathrm{~m})$ with some species also being found in deeper waters [31]. Barnacles are generally small but certain species can reach up to $75 \mathrm{~mm}$ tall (e.g., Chirona hameri [65].

Life Cycle

Barnacles have a complex life cycle undergoing several stages of development which includes six naupliar (planktotrophic) and a cyprid (non-feeding) instars, the juvenile stage and the sessile adult $[31,66,67]$. Barnacle development is mostly influenced by temperature [68]. The spawning of barnacle larvae is generally synchronized with spring phytoplankton blooms to assure the conditions are optimal for survival $[18,69]$. The larvae are free-swimming and can stay in the plankton for up to two months until they find a suitable substratum for settlement.

A major driver of larval settlement is conspecific chemical cues indicating the presence of other barnacles $[70,71]$ while on the other hand they may be repelled by the presence of predatory organisms [26]. During this process, the larvae hover across the substrata and secrete temporary adhesives to guide other incoming larvae to settle nearby resulting in a higher number of cues left by the larvae on attractive substrata [71]. Larvae seem to have a selective preference for hydrophilic substrata and with initially high critical surface energy [18]. Established bacterial biofilms may have either an inhibitory, neutral or attractive effect on barnacle larval settlement, depending on the species [72,73] and the settlement can be seen already within $1 \mathrm{~h}$ after submersing a substratum [18]. After settlement, the cyprid metamorphs into a juvenile barnacle with calcified shell plates. The barnacle continues to expand its base and side plates as it grows and molts throughout its life. Effective attachment to the substrata is assured using an insoluble cement composed of proteinaceous materials with an outer lipidic layer which hardens very fast after secretion $[67,74]$. 
2.3.5. Calcareous Tubeworms (Phylum Annelida, Class Polychaeta, Family Serpulidae)

Overview

Calcareous tubeworms (serpulids; Figure 6) are sedentary suspension-feeding organisms that live in calcareous tubes which they build to attach to the substrata (generally hard-substrata but can also be macroalgae). Serpulids can reach considerable lengths of up to $70 \mathrm{~mm}$ (e.g., Serpula vermicularis) and may be found at depths down to $200 \mathrm{~m}$ [75].

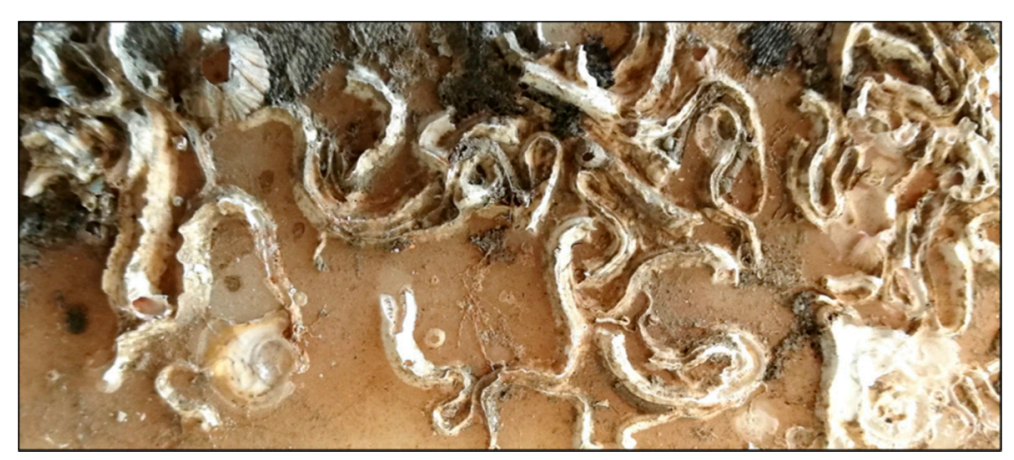

Figure 6. Serpulids (Spirobranchus sp.) growing on a nylon structure.

Life Cycle

Small species brood lecithotrophic larvae $(\sim 200 \mu \mathrm{m})$ while medium-large species broadcast-spawn planktotrophic larvae $(\sim 125-300 \mu \mathrm{m})$ [76,77]. Besides sexual reproduction, some serpulids also reproduce asexually by scissiparity. Development and reproduction are greatly affected by water temperature. In Europe, the spawning of serpulids may occur throughout the year and the settlement season may extend over several months [76]. Many serpulids show gregarious settlement and form conspecific complexes where derived individuals form tubes that branch off from their parent tubes [78]. Settlement can be elicited by the presence of a single adult and is delayed in the absence of cues associated with conspecifics [75-77]. Settlement can also be either induced or inhibited by biofilms and by macroalgal compounds [76]. After settlement, larvae metamorph into juveniles which begin to build the tube. Longevity correlates to size, with smaller species showing a lifespan of few years (e.g., 1.5-4 years for Spirobranchus triqueter) and larger species having longer lifespans (e.g., 18-35 years for S. giganteus) [76].

\subsection{Impact of Key Biofouling Groups to MRE Equipment}

The impact of biofouling is most often associated with alterations of the hydrodynamic properties, structural mass and roughness of submersed devices/components leading to loss of integrity and of performance or functionality $[79,80]$. A summary of each impact is presented below:

- Added weight to MRE equipment

Among the five biofouling groups mentioned above, mussels, barnacles and kelp are the most problematic with regards to added weight. Mussel assemblages rapidly add substantial weight to structures. For example, in one study offshore the Portuguese West coast, $M$. galloprovincialis registered $\sim 24 \mathrm{~kg}$ fresh weight $\mathrm{m}^{-2}$ on test panels submersed for 12 months at $5 \mathrm{~m}$ depth (Vinagre et al., 2019, unpublished data). In another study in the Mediterranean Sea, after a much longer period of equipment submersion (offshore gas platform piles submersed for $\sim 17.5$ years) assemblages of $M$. galloprovincialis registered $\sim 155 \mathrm{~kg}$ fresh weight $\mathrm{m}^{-2}$ near the surface [81]. While not as heavy as mussels, barnacles and bryozoans may also add considerable weight to structures. For example, offshore the Portuguese West coast, the barnacle Perforatus perforatus and the bryozoan cf. Bugula sp. registered $\sim 4-5 \mathrm{~kg}$ fresh weight $\mathrm{m}^{-2}$ on test panels submersed for 12 months, at depths of 10 and $5 \mathrm{~m}$, respectively (Vinagre et al., 2019, 
unpublished data). Colonies of the bryozoan Schizoporella errata from the Mediterranean Sea (on offshore gas platform piles submersed for $~ 17.5$ years) have further been recorded to also reach $\sim 5 \mathrm{~kg}$ fresh weight $\mathrm{m}^{-2}$ at a depth of $12 \mathrm{~m}$ [81]. Kelp assemblages regularly amount to great weights in their natural environment (e.g., up to $40 \mathrm{~kg}$ of fresh weight $\mathrm{m}^{-2}$ [30]). However, since they are close to neutrally buoyant, to MRE equipment kelp mainly cause increased drag of the moving parts [82].

- Added thickness/roughness to MRE equipment

Mussels, barnacles and, to lesser extent serpulids, bryozoans and kelp, further greatly increase the surface diameter/thickness and roughness of submersed devices and components leading to increased drag and reduced mobility of moving parts [82]. Furthermore, it is possible that the increased surface diameter/thickness of components could damage other, more sensitive components such as sealings from hydraulic components.

- Corrosion in MRE equipment

As mentioned in the Introduction, corrosion of MRE equipment may be induced and/or accelerated by micro- and macrofouling organisms [7,8]. Anaerobic marine microorganisms may induce MIC and macrofoulers may facilitate MIC initiated by those organisms growing under the macrofoulers in hypoxic/anoxic conditions. In addition, some macrofoulers may promote localized corrosion as they use chemicals to adhere to or perforate substrata [8,9]. While each of the five biofouling groups addressed in the current paper are capable of strongly adhering to substrata to different degrees, barnacles and serpulids generally show the greatest adhesion strength [83]. Of the two, barnacles are usually more difficult to remove from MRE equipment compared to serpulids, and they usually cause more severe implications [84]. This is often because it is frequently not possible to entirely remove barnacles without scratching the surface as their cement remains adhered to the surface upon removal, and this scratching may expose the surface to marine water and induce accelerated corrosion. The adhesion strength of barnacles specifically can be reduced using silicone coatings to which their attachment is weaker [85]. Kelp, mussels and bryozoans generally show weaker adhesion strength and are easier to remove during maintenance. However, the forces generated on these settled assemblies of organisms by currents and waves may cause abrasion of the devices/components due to their great weight or volume and accelerate corrosion as a consequence.

Maintenance plans for MRE projects are of paramount importance as maintenance is a very costly process that may account for up to almost a third of the operating costs for an MRE project [86]. Maintenance such as repair and inspection activities of MRE structures are carried out in situ, frequently offshore, during the service life of the setup [87]. Those activities require specific and expensive operational logistics such as vessels, professionals and equipment, and they further hinge on environmental conditions and weather. Since MRE equipment/structures are designed to optimally perform from 10 to 30 years, maintenance is especially relevant during mid to later stages of the operational lifespan, as current antifouling solutions may not be functional during the entire lifetime of the project $[87,88]$. Furthermore, maintenance activities also lead to downtime, preventing energy production and consequently causing loss in revenue. Because of the variable nature of biofouling and of its impacts on MRE structures/equipment, the biofouling database could be of especial importance for players in the MRE sector allowing them to be more aware of site-specific biofouling and aiding them in defining adequate maintenance plans including nature and frequency of activities.

\subsection{Biofouling Control}

Biofouling control has evolved especially in the last decade and it is anticipated that it will continue to do so, in particular in response to the changing environment [89]. Several extensive reviews have been published on the topic over the last 60 years (Table 1 ). 
Table 1. Key reviews on the theme of biofouling control over the last 60 years.

\begin{tabular}{|c|c|}
\hline Author & Title \\
\hline Redfield and Ketchum, 1952 [90] & Marine fouling and its prevention (Part III: Prevention of fouling) \\
\hline Fisher et al., 1984 [91] & Technology for control of marine biofouling-A review \\
\hline Wahl, 1989 [13] & Marine Epibiosis. I. Fouling and antifouling: Some basic aspects \\
\hline Swain, 1999 [92] & Redefining antifouling coatings \\
\hline Yebra et al., 2004 [46] & $\begin{array}{l}\text { Antifouling technology-Past, present and future steps towards } \\
\text { efficient and environmentally friendly antifouling coatings }\end{array}$ \\
\hline Chambers et al., 2006 [93] & Modern approaches to marine antifouling coatings \\
\hline Fusetani and Clare, 2006 [94] & Antifouling compounds \\
\hline Almeida et al., 2007 [95] & Marine paints: The particular case of antifouling paints \\
\hline Hellio and Yebra, 2009 [28] & Advances in marine antifouling coatings and technologies \\
\hline Magin et al., 2010 [96] & Non-toxic antifouling strategies \\
\hline Salta et al., 2010 [97] & Designing biomimetic antifouling surfaces \\
\hline Callow and Callow, 2011 [98] & $\begin{array}{l}\text { Trends in the development of environmentally friendly } \\
\text { fouling-resistant marine coatings }\end{array}$ \\
\hline Cao et al., 2011 [22] & Progress of marine biofouling and antifouling technologies \\
\hline Dafforn et al., 2011 [99] & $\begin{array}{l}\text { Antifouling strategies: History and regulation, ecological impacts } \\
\text { and mitigation }\end{array}$ \\
\hline Lejars et al., 2012 [5] & $\begin{array}{l}\text { Fouling release coatings: A nontoxic alternative to biocidal } \\
\text { antifouling coatings }\end{array}$ \\
\hline Buskens et al., 2013 [100] & $\begin{array}{l}\text { A brief review of environmentally benign antifouling and } \\
\text { foul-release coatings for marine applications }\end{array}$ \\
\hline Gittens et al., 2013 [101] & $\begin{array}{l}\text { Current and emerging environmentally-friendly systems for fouling } \\
\text { control in the marine environment }\end{array}$ \\
\hline Legg et al., 2015 [102] & Acoustic methods for biofouling control: A review \\
\hline Ciriminna et al., 2015 [103] & Ecofriendly antifouling-Marine coatings \\
\hline Amara et al., 2018 [104] & $\begin{array}{l}\text { Antifouling processes and toxicity effects of antifouling paints on } \\
\text { marine environment: A review }\end{array}$ \\
\hline Xie et al., 2019 [105] & Dynamic surface antifouling: Mechanism and systems \\
\hline Verma et al., 2019 [106] & A review on protective polymeric coatings for marine applications \\
\hline
\end{tabular}

Until recently, antifouling solutions mainly resided in the use of biocidal substances, mostly tributyltin (TBT) or copper-based [99]. While TBT was very effective, its pronounced persistence in sediments and bioaccumulation combined with substantial evidence of its significant environmental impacts on numerous non-targeted marine species such as mollusks and fish led to its global ban in 2008. As an alternative to TBT, the use of copper/zinc and booster biocides (e.g., Irgarol 1051, SeaNine 211 and Diuron) in antifouling paints became more frequent. Although these compounds are considered less harmful to the environment than TBT, similar problems associated with their toxicity and accumulation in the marine environment from their use have been reported $[46,99,104]$. These methodologies rely on the release of a biocidal or repelling compound to counter the settlement of organisms and the coating/paint in which those substances are incorporated need to be reapplied at regular intervals.

Having a coating where the organisms attach poorly is an alternative strategy and, to date, the majority of applied antifouling technologies rely on such fouling release-based coatings, which were extensively reviewed by Lejars et al. [5]. This has led to the development of numerous biocide-free antifouling solutions, such as silicone-based foul release coatings (e.g., Intersleek 900) capable of 
acting against both micro- and macrofouling organisms due to their amphiphilic surface nature and hydrogel paints (e.g., Hempasil X3) that form a water-retaining polymeric network over the coated surface and make the fouling organisms perceive the coated surface more as a liquid rather than a solid surface [103]. The fouling release coatings are efficient when employed under suitable conditions; however, the technology is optimized for moving objects and relies on the sheer forces induced from movement to remove the settled organisms [5]. As such, many of the silicone-based technologies are not optimized for the ocean energy sector with its many slow-moving or stationary marine installations.

With the development and expansion of maritime sectors such as ocean energy and aquaculture, the antifouling industry has grown proportionally [88,107]. Alternative antifouling technologies are therefore under constant development. While new technologies are being developed, they must adhere to the legislation applicable to antifoulants, namely The Biocidal Products Regulation (BPR, Regulation (EU) 528/2012) which governs the use of antifouling coatings and other products.

Creating coatings that are effective and repellent to settlement under stationary conditions is challenging and many different strategies are under development and consideration in addition to classic biocide and fouling release technologies. Some examples include mechanical cleaning, physical control by applying acoustics [102], pressure or UV radiation [108], electro-chemical treatment [109], iodine vapor [110] and the development of repellent micro- and nano-textures [111]. Several of these approaches are inspired by how stationary marine organisms cope with the threat of being overgrown and colonized [112,113]. Stationary and slow-moving marine organisms regularly employ either a physical or a chemical defense to prevent being overgrown and colonized by marine microand macroorganisms and many of these approaches are being investigated [114-116]. Biomimicry of natural repelling topographies such as shark skin, crab shells and plant leaves are thus under investigation $[117,118]$. Numerous antifouling natural products exert their repelling effect in a non-toxic reversible manner, and being able to mimic nature would potentially allow for environmentally-friendly coating technologies $[114,119,120]$. A challenge here lies in the economical production of large amounts of these compounds synthetically to meet demand, and structural simplification is one route to lower production costs $[114,116]$. In addition, reducing the release to a minimum or employing contact-active biocides embedded in a soft coating would lower the environmental burden [10,11].

For the marine energy sector, it is crucial that the antifouling is efficient, long acting and economical as these stationary structures are deployed for many years and repeated maintenance represents high costs for the sector [87]. Several types of structures may not need total protection from settling organisms, while, for other more delicate, moving parts, it is crucial. In addition, given the spread in devices employed, it is unlikely that single solutions would be applicable to the entire sector [121].

\subsection{Artificial Reef Effect: Non-Native Species and Regulatory Framework}

Any artificial structure deliberately placed in marine conditions will act as an artificial reef, attracting marine organisms and mimicking the functions of natural reefs [122]. Offshore structures, although serving a different purpose, can be regarded as artificial reefs creating new surfaces on which the organisms attach, settle and grow [123,124]. Therefore, offshore structures may act as promoters of ecosystem diversity and function and often present communities more diverse and abundant than those in the surroundings, including natural reefs and soft substratum [124]. Additionally, this may result in fish attraction and aggregation when compared to surrounding soft-bottom areas [122,123].

However, offshore structures may contribute to the propagation of NNS (including macroorganisms and microorganisms such as pathogens and parasites) in the marine environment, serving as "stepping stones" for the organisms [124-126]. The introduction of NNS often impacts biodiversity, habitats or ecological processes, and it may pose both ecological and economical threats [12].

Although requirements to biofouling control per se are non-existent worldwide, as a vector of NNS propagation, the biofouling aspect of maritime sectors has received attention especially in the last two decades and is now regarded in several international/European legislative frameworks (and in other national ones), for example: 
- 2004: The United Nations International Maritime Organization (IMO; http://www.imo.org) hosts the International Convention for the Control and Management of Ships' Ballast Water and Sediments (BWM) which provides standards and guidelines to prevent, minimize and furtherly eliminate the transfer of harmful organisms and pathogens in ballast waters and sediments.

- 2008: The EU Marine Strategy Framework Directive (MSFD, Directive 2008/56/EC; https://ec. europa.eu) enters into force aiming at a more effective protection of the marine environment and biodiversity. The MSFD intends for the Members States to achieve "Good Environmental Status" with assessment of 11 Descriptors including the D2-Non-Indigenous Species, through an adaptive management approach which must be kept up-to-date and reviewed every six years.

- 2011: The IMO Marine Environment Protection Committee (MEPC) adopts the IMO guidelines for the control and management of ships' biofouling to minimize the transfer of invasive aquatic species (resolution MEPC.207(62)), which was further supplemented by the 2012 guidance for minimizing the transfer of invasive aquatic species as biofouling (hull fouling) for recreational craft (MEPC.1/Circ.792).

- 2015: The EU Regulation on invasive alien species (IAS Regulation 1143/2014; https://ec.europa.eu) enters into force setting out rules to prevent, minimize and mitigate the adverse impacts caused by invasive species. The Regulation requires the Member States to study the introduction routes and spread of invasive species and to set up surveillance systems and action plans to ascertain the adequate preventive measures, among others.

Having all legislation pieces into account, it makes necessary to players in the MRE sector to develop biosecurity risk assessment/management plans aiming to predict and prevent the establishment and propagation of NNS as a condition of their projects. In this sense, the biofouling database presented in this paper could be especially useful since it provides beforehand a mapping of non-native species found across European waters. This awareness, in turn, may be helpful in the development of maintenance plans (mentioned in Section 2.4).

\section{European Biofouling Database}

\subsection{Database Description}

The biofouling database compiles data obtained from sampling biofouling communities in test-sites along European test-bed facilities as a part of the OCEANIC project. In addition, the database contains extensive data from peer-reviewed literature and reports, most of which are aimed at characterizing the biofouling communities growing on specific substrata in European waters. The search for literature included terms such as biofouling, macrofouling, fouling, marine growth, colonization and assemblages, combined with others such as artificial structures, European, marine renewable energy, ocean energy and offshore.

The compiled information describes the following attributes at each site to provide relevant biofouling information for the MRE sector:

- Realm, Province and Ecoregion (after [127]): Allows an overview of the countries encompassed in the mapping and provides insights of possible biofouling community patterns.

- Country and Site: Defines the country and location of the sampled. Non-European sites in the Mediterranean were included.

- Distance to shore: Defines the distance between the sampled site and the closest shore.

- Type of equipment/structure: Describes the surfaces surveyed, including equipment/structures from the MRE and oil and gas sectors; deliberate artificial reefs and test panels were included.

- Period of submersion: Defines the period (months/years) during which the biofouling could grow (i.e., from the equipment deployment until data was gathered).

- Depth: Defines the depth at which data was retrieved. 
- Temperature and wave height: Presents temperature and wave height data in the area sampled (or for the closest area). Data were retrieved from the cited work or from WindGuru (http://www.windguru.cz) for the area and fouling period.

- Biofouling data: Includes qualitative and quantitative information on samples collected in the field and on biofouling organisms found in the samples: kelp, bryozoans, mussels, acorn barnacles and calcareous tubeworms and other relevant sessile biofoulers including NNS. Taxonomy was standardized according to WoRMS (World Record of Marine Species) (http://www.marinespecies. org). Quantitative data on samples include biofouling weight and thickness and the biofoulers weight and size (length or height, depending on the species). Weight was standardized mainly to $\mathrm{kg}$ fresh weight $\mathrm{m}^{-2}$.

- Reference: Identifies the source of the biofouling data presented.

\subsection{Database Indicators}

The European biofouling database presented was initiated at the end of 2017 and has been available for download at the OCEANIC project website (http://oceanic-project.eu/biofouling-database) since mid-November 2018. It was presented at the ICOE 2018 conference and was disseminated at several international events about biofouling and/or the MRE sector (for example, EIMR 2018, ICMCF 2018, Business2Sea 2018, WavEC Annual Seminar 2018 and EWTEC 2019). The database has been downloaded from 20 countries worldwide, mostly from companies working in the MRE sector (Figure 7).

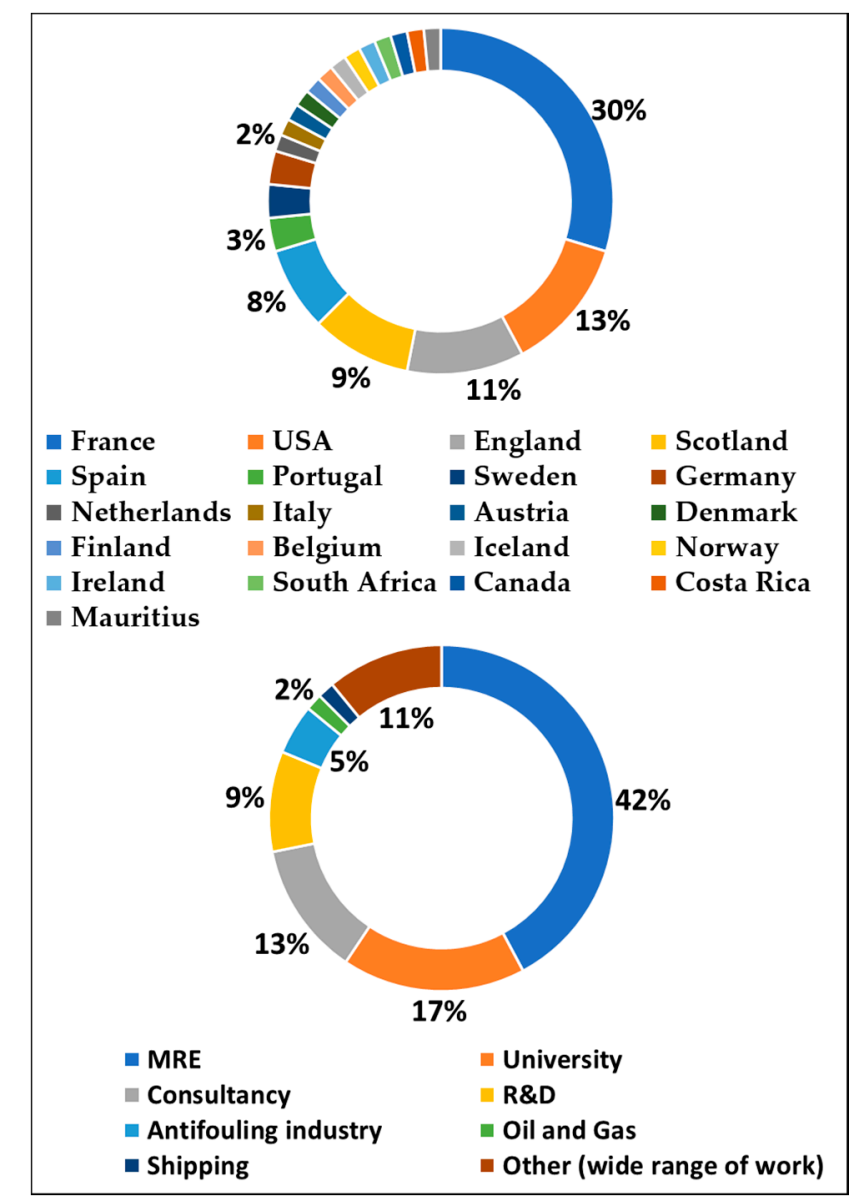

Figure 7. Distribution of the biofouling database downloads among countries and among sectors.

At present, the database encompasses nine Ecoregions that include 20 countries/areas (Table 2; Figure 8). The database covers data from structures deployed between onshore to $195 \mathrm{~km}$ 
offshore. The data span a depth range from the surface to $90 \mathrm{~m}$ depth and the submersion time ranges between 10 days and 39 years. The database describes and characterizes the settlement colonies on a range of different man-made structures and materials relevant to the MRE sector. Among the literature reviewed, more records were available for the North Sea Ecoregion in comparison to for example the Celtic Sea and White Sea Ecoregions (Figure 8). An overview of the data available for the different Ecoregions is summarized in Table 3 and the reader is referred to the database for detailed information about each site.

Table 2. Regions included in the European biofouling database.

\begin{tabular}{ccc}
\hline Region & Ecoregion & Countries \\
\hline I & South European Atlantic Shelf & Portugal, Spain (north coast), France (west coast) \\
II & Western Mediterranean Sea & Italy (west coast) \\
III & Adriatic Sea & Italy (east coast) \\
IV & Aegean Sea & Turkey (west coast) \\
V & Levantine Sea & Turkey (south coast), Egypt \\
VI & Celtic Seas & Ireland \\
VII & North Sea & England, Scotland, Belgium, Netherlands, Germany, \\
VIII & Baltic Sea & Denmark, Sweden (west coast), North Sea” \\
IX & White Sea & Sweden (east coast), Poland \\
\hline
\end{tabular}

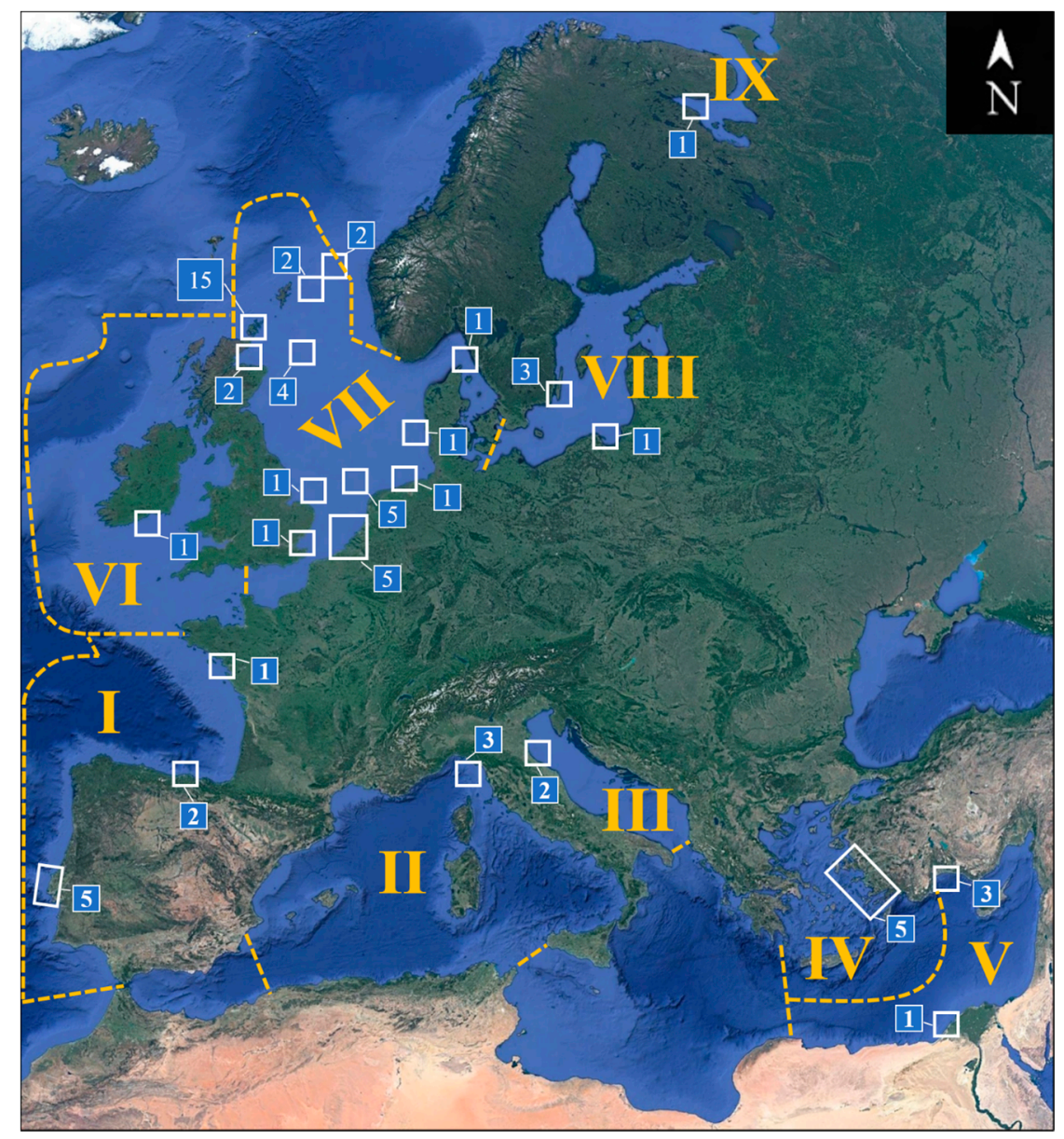

Figure 8. Overview of sites covered in the European biofouling database. Ecoregions key (yellow Roman numerals): I, South European Atlantic Shelf; II, Western Mediterranean Sea; III, Adriatic Sea; IV, Aegean Sea; V, Levantine Sea; VI, Celtic Seas; VII, North Sea; VIII, Baltic Sea; and IX, White Sea. Sites key (white squares): area and number of biofouling sampling records (surveys undertaken at different sites or during different periods at the same site). Base map: Google Earth. 
Table 3. Overview of the origin of the data used to generate the biofouling database.

\begin{tabular}{|c|c|c|c|c|c|c|}
\hline Region & $\begin{array}{l}\text { Country/ } \\
\text { Location }\end{array}$ & Records $^{a}$ & Structures & $\begin{array}{c}\text { Period } \\
\text { (months) }\end{array}$ & $\begin{array}{l}\text { Depth } \\
\text { (m) }\end{array}$ & $\begin{array}{l}\text { Distance } \\
(\mathbf{k m})\end{array}$ \\
\hline I & France & 1 & Moorings & $17-19$ & $0-25$ & 20 \\
\hline I & Portugal & 5 & $\begin{array}{c}\text { Metallic and plastic panels, Rubber } \\
\text { seals }\end{array}$ & $7.5-17$ & $0-10$ & Onshore- 0.4 \\
\hline I & Spain & 2 & Metallic and plastic panels & 5 and 9 & 25 & 1.7 \\
\hline II & Italy & 3 & Buoys, panels & $3-70$ & $0-39$ & 55 and 68.5 \\
\hline III & Italy & 2 & Gas platform piles & $204-209$ & $0-12$ & 10.5 \\
\hline IV & Turkey & 5 & Asbestos-cement panels & $3-12$ & 3 & 0.1 \\
\hline $\mathrm{V}$ & Egypt & 1 & Polystyrene panels & 1 & $0-5.5$ & 0.5 \\
\hline $\mathrm{V}$ & Turkey & 3 & Wood panels & 13 & $0-1$ & 0.1 \\
\hline VI & Ireland & 1 & Gas platform piles & $15-51$ & $3-90$ & 50 \\
\hline VII & Belgium & 4 & Monopiles, concrete foundations & $2-45$ & $0-25$ & 30 and 49 \\
\hline VII & Denmark & 1 & Monopiles & $12-42$ & $0-10$ & 14 \\
\hline VII & England & 2 & Monopiles & 31 & $0-10$ & $10-50$ \\
\hline VII & Germany & 1 & Jacket foundation & $21-51$ & $0-28$ & 45 \\
\hline VII & Netherlands & 6 & Monopiles, jacket foundations & $18-468$ & $0-43$ & $18-177$ \\
\hline VII & North Sea & 4 & Oil and gas platforms, clamps & $36-180$ & $0-67$ & $100-115$ \\
\hline VII & Scotland & 21 & $\begin{array}{l}\text { Jacket foundations, piles, buoys, } \\
\text { chains, ADCP, WEC, pontoons, } \\
\text { harbor walls, metallic panels }\end{array}$ & $11-60$ & 0-90 & $0.1-195$ \\
\hline VII & Sweden & 1 & Concrete foundation & $2-26$ & $0-25$ & 2 \\
\hline VIII & Poland & 1 & PVC panels & $0.3-2$ & $3-7$ & 0.35 \\
\hline VIII & Sweden & 3 & Bridge pillars, monopiles, boulders & $24-300$ & $1.5-5$ & Onshore-12 \\
\hline IX & Russia & 1 & Ceramic panels & $2-13$ & 1.5 & 0.1 \\
\hline
\end{tabular}

Each separate location in the database is closely mapped and the extent of the biofouling of the investigated structure/materials is characterized and described in terms of weight, thickness and species composition. An example of a summarized data entry from the database is shown in Table 4.

There is a wide range in the time exposed to the marine environment with some structures being exposed for a few months while others were analyzed after 17 years in the ocean. While this provides highly relevant insights into the biofouling process on made-made structures over time, caution is warranted when comparing the absolute amounts between sites. The biofouling community structures changes among the Ecoregions and significantly within each Ecoregion, and different organisms become frequent in the communities at different depths. Nonetheless, the biofouling groups dominant in the communities were frequently the same; for example, the bulk of the biofouling weight was most frequently associated with colonization by mussels and acorn barnacles reaching as high as $150 \mathrm{~kg} / \mathrm{m}^{2}$ accumulated over 17 years in the Adriatic Sea (Region III). A very general zonation pattern reflecting the literature and reports reviewed could be described as follows:

- The number of species increases with depth within the euphotic region down to about $40 \mathrm{~m}$. Upper sections present greater biofouling weight $(0-10 \mathrm{~m})$ and thickness $(0-20 \mathrm{~m})$.

- Upper intertidal sections (0-6 m) are dominated by ephemeral green, red and brown algae and barnacles (e.g., Semibalanus balanoides). Below, kelp (e.g., Laminaria sp.) may develop down to mid water column sections depending on light availability and on seawater temperature, especially in the North Sea.

- From the lower intertidal to the infralittoral (down to about $30 \mathrm{~m}$ ), bands of barnacles (e.g., S. balanoides, Balanus crenatus) and mussels (e.g., M. edulis, M. galloprovincialis) occur. The biomass of these organisms decreases with increasing depth down to $90 \mathrm{~m}$. They are accompanied by a plethora of additional sessile organisms including serpulids (e.g., Spirobranchus sp., Hydroides sp.), anemones (e.g., Metridium senile, Sagartia sp.), hydrozoans (e.g., Tubularia/Ectopleura sp.), soft corals (e.g., Alcyonium digitatum) and sea-squirts (e.g., Ascidiella aspersa). In addition, a great variety of mobile organisms such as crustaceans (e.g., decapods: Pachygrapsus marmoratus, Pilumnus hirtellus; amphipods: Jassa sp.) and echinoderms (e.g., Asterias rubens, Paracentrotus lividus) is found. 
- The seabed is occupied by mobile organisms such as decapods and starfishes which predate on organisms such as mussels and barnacles and restrict their lower (deeper) limit.

Table 4. Example of the European biofouling database structure.

\begin{tabular}{|c|c|c|c|c|c|}
\hline \multicolumn{6}{|c|}{ Sampling Location Information } \\
\hline \multicolumn{3}{|c|}{ Realm $^{\mathrm{a}}$} & \multicolumn{3}{|c|}{ Temperate Northern Atlantic } \\
\hline \multicolumn{3}{|c|}{ Province $^{\text {a }}$} & \multicolumn{3}{|c|}{ Lusitanean } \\
\hline \multicolumn{3}{|c|}{ Ecoregion ${ }^{\mathrm{a}}$} & \multicolumn{3}{|c|}{ South European Atlantic Shelf } \\
\hline \multicolumn{3}{|c|}{ Country-city } & \multicolumn{3}{|c|}{ Portugal-Peniche } \\
\hline \multicolumn{3}{|c|}{ Site } & \multicolumn{3}{|c|}{ AW-Energy WaveRoller test site } \\
\hline \multicolumn{3}{|c|}{ Coordinates } & \multicolumn{3}{|c|}{$39^{\circ} 22^{\prime} 56.64^{\prime \prime} \mathrm{N}, 9^{\circ} 18^{\prime} 58.68^{\prime \prime} \mathrm{W}$} \\
\hline \multicolumn{3}{|c|}{ Distance to land } & \multicolumn{3}{|c|}{$0.4 \mathrm{~km}$} \\
\hline \multicolumn{3}{|c|}{ Equipment } & \multicolumn{3}{|c|}{ Metallic and plastic test panels } \\
\hline \multicolumn{3}{|c|}{ Fouling period } & \multicolumn{3}{|c|}{12 months } \\
\hline \multirow{2}{*}{\multicolumn{3}{|c|}{ Depth }} & \multicolumn{3}{|c|}{$5-10 \mathrm{~m}$} \\
\hline \multicolumn{2}{|c|}{ Temperature } & & \multicolumn{3}{|c|}{$12.9^{\circ} \mathrm{C}$ (January)-20.2 ${ }^{\circ} \mathrm{C}$ (August) } \\
\hline \multicolumn{3}{|c|}{ Wave height } & \multicolumn{3}{|c|}{$1.6 \mathrm{~m}$ (September)-3.1 m (February) } \\
\hline \multicolumn{6}{|c|}{ Biofouling Sample } \\
\hline \multirow{2}{*}{\multicolumn{3}{|c|}{$\begin{array}{l}\text { Sample maximum thickness } \\
\text { Sample maximum weight }\end{array}$}} & \multirow{2}{*}{\multicolumn{3}{|c|}{$\begin{array}{c}83.7 \mathrm{~mm}(\text { at } 5 \mathrm{~m}) \\
33.5 \mathrm{~kg} \text { fresh weight } \mathrm{m}^{-2}(\text { at } 5 \mathrm{~m})\end{array}$}} \\
\hline & & & & & \\
\hline \multicolumn{6}{|c|}{ Biofouling Organisms } \\
\hline Group $^{b}$ & Sub-group ${ }^{b}$ & Species $^{b}$ & Common Name ${ }^{b}$ & Max. Size ${ }^{c}$ & Max Weight ${ }^{d}$ \\
\hline \multirow[t]{2}{*}{ Polychaeta } & \multirow[t]{2}{*}{ Serpulidae } & Hydroides sp. & Tubeworm & - & - \\
\hline & & Spirobranchus sp. & Christmas tree worms & - & - \\
\hline Bryozoa & Gymnolaemata & Bugula sp. & Bryozoan & - & $3.7^{\mathrm{e}}$ \\
\hline Crustacea & Cirripedia & Perforatus perforatus & Acorn barnacle & $22.1^{\mathrm{e}}$ & $5.1^{\mathrm{e}}$ \\
\hline \multirow[t]{4}{*}{ Mollusca } & \multirow[t]{4}{*}{ Bivalvia } & Anomia ephippium & Saddle oyster & $5.9^{f}$ & $0.001^{\mathrm{f}}$ \\
\hline & & Hiatella arctica & Wrinkled rock borer & $12.1^{\mathrm{e}}$ & $0.05^{\mathrm{e}}$ \\
\hline & & Musculus costulatus & Flat striped shell & - & - \\
\hline & & Mytilus galloprovincialis & Mediterranean mussel & $89.6^{\mathrm{e}}$ & $23.8^{\mathrm{e}}$ \\
\hline
\end{tabular}

${ }^{a}$ Ref. [127]; ${ }^{\mathrm{b}}$ WoRMS, http://www.marinespecies.org; ${ }^{\mathrm{c}}$ in $\mathrm{mm} ;{ }^{\mathrm{d}}$ in $\mathrm{kg}$ fresh weight $\mathrm{m}^{-2} ;{ }^{\mathrm{e}}$ at $10 \mathrm{~m} ;{ }^{\mathrm{f}}$ at $5 \mathrm{~m}$.

The literature review allowed the identification of 18 marine NNS (Table 5). The NNS were found mostly within the North Sea and at the intertidal section of submerged structures and included eight hard-foulers (six barnacles, one bivalve and two gastropods) and one soft-/hard-fouler (bryozoan). 
Table 5. Non-native species identified in the literature reviewed and countries where they were reported.

\begin{tabular}{|c|c|c|c|c|c|}
\hline \multicolumn{2}{|c|}{ Biofouling } & Group $^{a}$ & Species & Common Name & Country $b$ \\
\hline \multirow{3}{*}{ Algae } & \multirow{8}{*}{ Soft-fouling } & Cl. Phaeophyceae & Colpomenia peregrina & Oyster thief & Sco \\
\hline & & Ph. Chlorophyta & Codium fragile fragile & Sponge seaweed & Sco \\
\hline & & Ph. Rhodophyta & Dasysiphonia japonica & Siphoned Japan weed & Sco \\
\hline \multirow{15}{*}{ Invertebrates } & & Or. Diptera & Telmatogeton japonicus & Marine splash midge & Bel, Den, Net, Swe \\
\hline & & & Jassa marmorata & Amphipod & Bel, Den, Eng, Net \\
\hline & & S.Ph. Crustacea & Caprella mutica & Japanese skeleton shrimp & Den, Net, Sco \\
\hline & & & Hemigrapsus sanguineus & Pacific crab, Asian shore crab & Bel \\
\hline & & Ph. Chordata & Corella eumyota & Orange-tipped sea squirt & Sco \\
\hline & \multirow{10}{*}{ Hard-fouling } & Ph. Bryozoa & Schizoporella japonica & Orange ripple bryozoan & Sco \\
\hline & & & Amphibalanus amphitrite & Striped barnacle & Bel \\
\hline & & & Austrominius modestus & Australasian barnacle & Bel, Sco, Eng, Net, Pt \\
\hline & & & Balanus glandula & North American barnacle & Bel \\
\hline & & S.Ph. Crustacea & Megabalanus coccopoma & Titan acorn barnacle & Bel, Net \\
\hline & & & Megabalanus tintinnabulum & Sea tulip & Bel \\
\hline & & & Perforatus perforatus & Acorn barnacle & Bel, Net \\
\hline & & & Magallana gigas & Pacific oyster & Bel, Ger, Ita, Net \\
\hline & & Ph. Mollusca & Crepidula fornicata & American slipper limpet & Bel \\
\hline & & & Patella vulgata & Common limpet & Bel \\
\hline
\end{tabular}

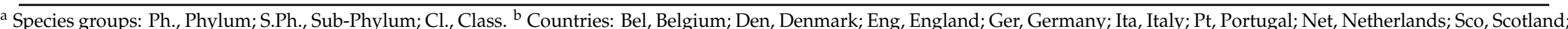
Swe, Sweden. 


\section{Discussion}

The complex biological origin and subsequent management of biofouling is widely reviewed and discussed, particularly in relation to its impacts and control in the maritime sectors (Table 1). Despite this significant amount of published material, it has been argued recently that the information is not being well or sufficiently transferred among developers, regulatory bodies and ecologists across the MRE sector [2]. The number of published studies may also complicate extracting key information relating to the MRE sector. These challenges may lead to improper design of operation and maintenance methodologies, consequently translating to increased costs and delays for MRE sector.

The development of the present European biofouling database was envisioned in the OCEANIC project to allow the MRE sector and other maritime sectors easy access to relevant biofouling data allowing more informed and quick decisions with regards to for example site selection and maintenance frequency. At present, the database includes in one document qualitative and quantitative data on key biofouling groups to the MRE sector, gathered during the three years of the OCEANIC project and from peer-reviewed papers and reports. The database, which is downloadable from the OCEANIC project website (http://oceanic-project.eu/biofouling-database) will continuously be updated with data from published papers and reports and with data shared by other projects, for example the recently finished H2020 project WaveBoost (https://ec.europa.eu/inea/en/horizon-2020/ projects/h2020-energy/ocean/waveboost) and the recently started OCEANERA-NET project SeaSnake (https://oceanenergy-sweden.se/seasnake). WavEC Offshore Renewables researchers will be in charge of the ongoing database updates. Collaboration between groups developing biofouling databases [128] is anticipated to be useful to develop a database as robust and applicable as possible.

For the present database, biofouling data were selected/discarded according to some attributes to make them as standardized, relevant and robust as possible. In addition to the geographical, physical and biological parameters presented in Table 4, the following design/selection criteria were applied to the database entries:

- Only sessile organisms were included. Mobile organisms such as decapods, amphipods or starfish may still be a dominant constituent of the communities at certain depths (regarding density or coverage, since the bulk of weight and thickness is generally associated to sessile organisms). Sessile organisms are unable to freely move along artificial structures and allow for an easier understanding of biofouling zonation across depths. Furthermore, the stationary fouling organisms represent the main challenge associated with cleaning and maintenance of marine structures.

- The weight and thickness of the biofouling communities were used throughout the study and extracted from the literature as the biofouling parameters most responsible for the impacts to the MRE as opposed to density (number of organisms) and/or coverage percentage. This is because weight and thickness better reflect the magnitude of the biofouling impact such as loading, potential increased drag or altered hydrodynamic properties. Furthermore, several of the attached organisms are challenging to quantify by other means and large coverage or density does not necessarily translate into a great weight or thickness.

- The month/season during which data were obtained and the bathymetry where the sampled structured is placed were not included due to scarcity of data. Time of sampling remains an important factor, particularly for short periods of biofouling growth where sampling after the spring-summer period (which is the period when growth and reproduction rates are enhanced) could yield different results compared to sampling after the autumn-winter period (when severe environmental conditions may not only cause reduced growth and reproduction rates, but also may cause the displacement of organisms by larger waves). Nonetheless, the database includes data from an extensive range of submersion periods (up to 17 years) which is perceived as extensive enough to cover for seasonality bias. The depth (bathymetry) influences the structure of biofouling communities, especially in shallow waters which are generally more turbulent and have greater variation in physical-chemical parameters such as temperature and turbidity that influence 
the biofouling composition and abundance (biomass, density and coverage), compared to deeper waters. The bathymetry parameter may be added to the database in the future (including for the present sites).

As acknowledged by researchers, predicting and modeling biofouling composition and magnitude, either at the micro- or macrofouling level or both, can be a daunting task, which makes biofouling management highly complex. The differences in biofouling communities at different geographic locations and biotopes adds further complexity and illustrates the need for tailormade and flexible antifouling solutions. The biofouling database can be used to assess the likely biofouling pressure at different locations and Europe and allows for informed decisions on antifouling countermeasures.

Modeling biofouling is expected to be further aggravated by the current scenario of climate change leading to ocean warming and acidification and sea level rise, among other impacts (IPCC 2013). Consequently, several environmental parameters influencing the biology of marine organisms including biofoulers have been and will be affected [89]. Key changes in the biofouling communities' structure are expected worldwide because of increased water temperature, for example in facilitating biological invasions especially in polar and temperate regions where cold-water native species may be replaced by warm-water NNS. Structural changes may further be aggravated by the decreased $\mathrm{pH}$ which may be detrimental to the calcification of hard-fouling organisms such as barnacles, mussels and bryozoans, possibly causing them to lose dominance in biofouling assemblages to soft-fouling organisms such as tunicates and algae [89].

Bearing in mind the impact of climate change in biofouling communities, the European biofouling database could be especially useful in the future as it will be updated regularly allowing for comparison of biofouling patterns across different time scales and locations. As such, the database is expected to be a useful and versatile tool for understanding the fouling pressure on different substrata in European waters and it is anticipated to find continued use in both commercial and academic research settings.

Author Contributions: Conceptualization, P.A.V., T.S., E.P. and J.S.; methodology, P.A.V., T.S., E.P. and J.S.; validation, P.A.V., T.S. and J.S.; formal analysis, P.A.V., T.S. and J.S.; resources, all authors; data curation, P.A.V.; writing-original draft preparation, all authors; writing—review and editing, P.A.V., T.S. and J.S.; visualization, P.A.V. and J.S.; supervision, P.A.V., T.S., E.P. and J.S.; project administration, all authors; and funding acquisition, T.S. and E.P. All authors have read and agreed to the published version of the manuscript.

Funding: This research was funded by FCT (Portuguese Foundation for Science and Technology), SWEA (Swedish Energy Agency), SPRI (Basque Business Development Agency), EVE (Energy Agency of the Basque Government) and CDTI (Spanish Centre for the Development of Industrial Technology) through OCEANERA-NET (Ocean Energy European Research Network) under the reference OCEANERA/0005/2014.

Acknowledgments: The authors thank the OCEANIC partners CorPower Ocean (Hägersten, Sweden), Gaiker (Zamudio, Spain), IK4-Azterlan (Durango, Spain), Repol (Almazora, Spain), RISE (Borås, Sweden), WavEC (Lisboa, Portugal), Skandinavisk Ytförädling (Eslöv, Sweden) and Recubrimientos Mikra (Idiazabal, Spain)for the support during the project.

Conflicts of Interest: The authors declare no conflict of interest. The funders had no role in the design of the study; in the collection, analyses, or interpretation of data; in the writing of the manuscript, or in the decision to publish the results.

\section{References}

1. Titah-Benbouzid, H.; Benbouzid, M. Biofouling issue on marine renewable energy converters: A state of the art review on impacts and prevention. Int. J. Energy Convers. 2017, 5, 67-78. [CrossRef]

2. Loxton, J.; Macleod, A.K.; Nall, C.R.; McCollin, T.; Machado, I.; Simas, T.; Vance, T.; Kenny, C.; Want, A.; Miller, R.G. Setting an agenda for biofouling research for the marine renewable energy industry. Int. J. Mar. Energy 2017, 19, 292-303. [CrossRef]

3. Ayers, J.; Turner, H. The principal fouling organisms. In Marine Fouling and Its Prevention; Redfield, A., Ketchum, B., Eds.; United States Naval Institute: Annapolis, MD, USA, 1952; pp. 118-164.

4. Richmond, M.; Seed, R. A review of marine macrofouling communities with special reference to animal fouling. Biofouling 1991, 3, 151-168. [CrossRef] 
5. Lejars, M.N.; Margaillan, A.; Bressy, C. Fouling release coatings: A nontoxic alternative to biocidal antifouling coatings. Chem. Rev. 2012, 112, 4347-4390. [CrossRef]

6. Videla, H.A.; Herrera, L.K. Microbiologically influenced corrosion: Looking to the future. Int. Microbiol. 2005, 8, 169-180.

7. Jia, R.; Unsal, T.; Xu, D.; Lekbach, Y.; Gu, T. Microbiologically influenced corrosion and current mitigation strategies: A state of the art review. Int. Biodeterior. Biodegrad. 2019, 137, 42-58. [CrossRef]

8. Kleemann, K. Biocorrosion by Bivalves. Mar. Ecol. 1996, 17, 145-158. [CrossRef]

9. Blackwood, D.J.; Lim, C.S.; Teo, S.L.; Hu, X.; Pang, J. Macrofouling induced localized corrosion of stainless steel in Singapore seawater. Corros. Sci. 2017, 129, 152-160. [CrossRef]

10. Pinori, E.; Berglin, M.; Brive, L.M.; Hulander, M.; Dahlström, M.; Elwing, H. Multi-seasonal barnacle (Balanus improvisus) protection achieved by trace amounts of a macrocyclic lactone (ivermectin) included in rosin-based coatings. Biofouling 2011, 27, 941-953. [CrossRef]

11. Pinori, E.; Elwing, H.; Berglin, M. The impact of coating hardness on the anti-barnacle efficacy of an embedded antifouling biocide. Biofouling 2013, 29, 763-773. [CrossRef]

12. Keller, R.P.; Geist, J.; Jeschke, J.M.; Kühn, I. Invasive species in Europe: Ecology, status, and policy. Environ. Sci. Eur. 2011, 23, 1-17. [CrossRef]

13. Wahl, M. Marine epibiosis. I. Fouling and antifouling: Some basic aspects. Mar. Ecol. Prog. Ser. 1989, 58, 175-189. [CrossRef]

14. Abarzua, S.; Jakubowski, S. Biotechnological investigation for the prevention of biofouling. I. Biological and biochemical principles for the prevention of biofouling. Mar. Ecol. Prog. Ser. 1995, 123, 301-312. [CrossRef]

15. Railkin, A.I. Marine Biofouling: Colonization Processes and Defenses; CRC press: Boca Raton, FL, USA, 2003; p. 303.

16. Clare, A.; Rittschof, D.; Gerhart, D.; Maki, J. Molecular approaches to nontoxic antifouling. Invertebr. Reprod. Dev. 1992, 22, 67-76. [CrossRef]

17. Maki, J.; Mitchell, R. Biofouling in the marine environment. In Encyclopedia of Environmental Microbiology; Bitton, G., Ed.; Wiley \& Sons: New York, NY, USA, 2002; pp. 610-619.

18. Roberts, D.; Rittschof, D.; Holm, E.; Schmidt, A. Factors influencing initial larval settlement: Temporal, spatial and surface molecular components. J. Exp. Mar. Biol. Ecol. 1991, 150, 203-221. [CrossRef]

19. Terlizzi, A.; Faimali, M. Fouling on artificial substrata. In Biofouling; Dürr, S., Thomason, J.C., Eds.; Blackwell Publishing Ltd.: Chichester, UK, 2010; pp. 170-184.

20. Rittschof, D. Research on practical environmentally benign antifouling coatings. In Biofouling; Dürr, S., Thomason, J.C., Eds.; Blackwell Publishing Ltd.: Chichester, UK, 2010; pp. 396-409.

21. Lehaitre, M.; Delauney, L.; Compère, C. Biofouling and underwater measurements. In Real-Time Observation Systems for Ecosystem Dynamics Harmful Algal Blooms: Theory, Instrumentation Modelling; Babin, M., Roesler, C.S., Cullen, J.J., Eds.; UNESCO Publishing: Paris, France, 2008; pp. 463-493.

22. Cao, S.; Wang, J.; Chen, H.; Chen, D. Progress of marine biofouling and antifouling technologies. Chin. Sci. Bull. 2011, 56, 598-612. [CrossRef]

23. Van Der Stap, T.; Coolen, J.W.P.; Lindeboom, H.J. Marine Fouling Assemblages on Offshore Gas Platforms in the Southern North Sea: Effects of Depth and Distance from Shore on Biodiversity. PLoS ONE 2016, 11, e0146324. [CrossRef] [PubMed]

24. Dayton, P.K. Competition, disturbance, and community organization: The provision and subsequent utilization of space in a rocky intertidal community. Ecol. Monogr. 1971, 41, 351-389. [CrossRef]

25. Raffaelli, D.; Hawkins, S.J. Intertidal Ecology; Kluwer Academic Publishers: Dordrecht, The Netherlands, 1999; p. 365.

26. Johnson, L.E.; Strathmann, R.R. Settling barnacle larvae avoid substrata previously occupied by a mobile predator. J. Exp. Mar. Biol. Ecol. 1989, 128, 87-103. [CrossRef]

27. Newell, R.; Branch, G. The influence of temperature on the maintenance of metabolic energy balance in marine invertebrates. In Advances in Marine Biology; Blaxter, J.H.S., Russell, F.S., Yonge, M., Eds.; Elsevier: London, UK, 1980; Volume 17, pp. 329-396.

28. Hellio, C.; Yebra, D. Advances in Marine Antifouling Coatings and Technologies; CRC Press: Boca Raton, FL, USA, 2009; p. 785.

29. Almeida, L.P.; Coolen, J.W.P. Modelling thickness variations of macrofouling communities on offshore platforms in the Dutch North Sea. J. Sea Res. 2020, 156, 1-8. [CrossRef] 
30. Bartsch, I.; Wiencke, C.; Bischof, K.; Buchholz, C.M.; Buck, B.H.; Eggert, A.; Feuerpfeil, P.; Hanelt, D.; Jacobsen, S.; Karez, R. The genus Laminaria sensu lato: Recent insights and developments. Eur. J. Phycol. 2008, 43, 1-86. [CrossRef]

31. Foster, B. Barnacle ecology and adaptation. In Barnacle Biology; Southward, A.J., Ed.; A.A. Balkema: Rotterdam, The Netherlands, 1987; pp. 113-133.

32. Koehl, M. Mini review: Hydrodynamics of larval settlement into fouling communities. Biofouling 2007, 23, 357-368. [CrossRef] [PubMed]

33. Swain, G.; Anil, A.; Baier, R.E.; Chia, F.S.; Conte, E.; Cook, A.; Hadfield, M.; Haslbeck, E.; Holm, E.; Kavanagh, C. Biofouling and barnacle adhesion data for fouling-release coatings subjected to static immersion at seven marine sites. Biofouling 2000, 16, 331-344. [CrossRef]

34. Kamino, K. Mini-review: Barnacle adhesives and adhesion. Biofouling 2013, 29, 735-749. [CrossRef]

35. Rittschof, D.; Orihuela, B.; Stafslien, S.; Daniels, J.; Christianson, D.; Chisholm, B.; Holm, E. Barnacle reattachment: A tool for studying barnacle adhesion. Biofouling 2008, 24, 1-9. [CrossRef] [PubMed]

36. Whitehead, K.; Verran, J. The effect of substratum properties on the survival of attached microorganisms on inert surfaces. In Marine and Industrial Biofouling; Flemming, H.C., Murthy, P.S., Venkatesan, R., Cooksey, K., Eds.; Springer: Berlin/Heidelberg, Germany, 2009; pp. 13-33.

37. Pomerat, C.; Weiss, C. The influence of texture and composition of surface on the attachment of sedentary marine organisms. Biol. Bull. 1946, 91, 57-65. [CrossRef]

38. Aldred, N.; Scardino, A.; Cavaco, A.; De Nys, R.; Clare, A.S. Attachment strength is a key factor in the selection of surfaces by barnacle cyprids (Balanus amphitrite) during settlement. Biofouling 2010, 26, 287-299. [CrossRef] [PubMed]

39. Scardino, A.; Guenther, J.; De Nys, R. Attachment point theory revisited: The fouling response to a microtextured matrix. Biofouling 2008, 24, 45-53. [CrossRef]

40. Scardino, A.J.; De Nys, R. Mini review: Biomimetic models and bioinspired surfaces for fouling control. Biofouling 2011, 27, 73-86. [CrossRef]

41. Clare, A.; Aldred, N. Surface colonisation by marine organisms and its impact on antifouling research. In Advances in Marine Antifouling Coatings and Technologies; Hellio, C., Yebra, D., Eds.; Woodhead Publishing Ltd.: Cambridge, UK, 2009; pp. 46-79.

42. Dahlem, C.; Moran, P.; Grant, T. Larval settlement of marine sessile invertebrates on surfaces of different colour and position. Ocean Sci. Eng. 1984, 9, 225-236.

43. Swain, G.; Herpe, S.; Ralston, E.; Tribou, M. Short-term testing of antifouling surfaces: The importance of colour. Biofouling 2006, 22, 425-429. [CrossRef] [PubMed]

44. Dobretsov, S.; Dahms, H.U.; Qian, P.Y. Inhibition of biofouling by marine microorganisms and their metabolites. Biofouling 2006, 22, 43-54. [CrossRef] [PubMed]

45. Dobretsov, S.; Abed, R.M.; Voolstra, C.R. The effect of surface colour on the formation of marine micro and macrofouling communities. Biofouling 2013, 29, 617-627. [CrossRef] [PubMed]

46. Yebra, D.M.; Kiil, S.; Dam-Johansen, K. Antifouling technology-Past, present and future steps towards efficient and environmentally friendly antifouling coatings. Prog. Org. Coat. 2004, 50, 75-104. [CrossRef]

47. Steneck, R.S.; Graham, M.H.; Bourque, B.J.; Corbett, D.; Erlandson, J.M.; Estes, J.A.; Tegner, M.J. Kelp forest ecosystems: Biodiversity, stability, resilience and future. Environ. Conserv. 2002, 29, 436-459. [CrossRef]

48. Gallardo, T. Marine Algae: General Aspect (Biology, Systematics, Fields and Laboratory Techniques). In Marine Algae: Biodiversity, Taxonomy, Environmental Asessment, Biotechnology; Pereira, L., Neto, J.M., Eds.; CRC Press: Boca Raton, FL, USA, 2015; pp. 1-67.

49. Streftaris, N.; Zenetos, A.; Papathanassiou, E. Globalisation in marine ecosystems: The story of non-indigenous marine species across European seas. In Oceanography and Marine Biology; Gibson, R.N., Atkinson, R.J.A., Gordon, J.D.M., Eds.; CRC Press: Boca Raton, FL, USA, 2005; pp. 419-453.

50. Guiry, M.; Guiry, G. AlgaeBase: World-Wide Electronic Publication; National University of Ireland: Galway, Ireland, 2019. Available online: https://www.algaebase.org/ (accessed on 23 March 2020).

51. Ryland, J. Behaviour, Settlement and Metamorphosis of Bryzoan Larvae: A Review. Thalass. Jugosl. 1974, 10, 239-262.

52. Soule, J.D.; Soule, D.F. Fouling and bioadhesion: Life strategies of bryozoans. In Biology of Bryozoans; Woollacott, R.M., Zimmer, R.L., Eds.; Academic Press: New York, NY, USA, 1977; pp. 437-457. 
53. Ostrovsky, A.N. Evolution of Sexual Reproduction in Marine Invertebrates: Example of Gymnolaemate Bryozoans; Springer: Dordrecht, The Netherlands, 2013; p. 356.

54. Mihm, J.W.; Banta, W.C.; Loeb, G.I. Effects of adsorbed organic and primary fouling films on bryozoan settlement. J. Exp. Mar. Biol. Ecol. 1981, 54, 167-179. [CrossRef]

55. Prendergast, G.S. Settlement and behaviour of marine fouling organisms. In Biofouling; Dürr, S., Thomason, J.C., Eds.; Blackwell Publishing Ltd.: Chichester, UK, 2010; pp. 30-59.

56. Westerbom, M.; Kilpi, M.; Mustonen, O. Blue mussels, Mytilus edulis, at the edge of the range: Population structure, growth and biomass along a salinity gradient in the north-eastern Baltic Sea. Mar. Biol. Res. 2002, 140, 991-999.

57. Bayne, B. Marine Mussels: Their Ecology and Physiology; Cambridge University Press: Cambridge, UK, 1976; Volume 10, p. 506.

58. Widdows, J. Physiological ecology of mussel larvae. Aquaculture 1991, 94, 147-163. [CrossRef]

59. Dinesen, G.E.; Morton, B. Review of the functional morphology, biology and perturbation impacts on the boreal, habitat-forming horse mussel Modiolus modiolus (Bivalvia: Mytilidae: Modiolinae). Mar. Biol. Res. 2014, 10, 845-870. [CrossRef]

60. Southgate, T.; Myers, A. Mussel fouling on the Celtic Sea Kinsale field gas platforms. Estuar. Coast. Shelf Sci. 1985, 20, 651-659. [CrossRef]

61. Bao, W.Y.; Satuito, C.G.; Yang, J.L.; Kitamura, H. Larval settlement and metamorphosis of the mussel Mytilus galloprovincialis in response to biofilms. Mar. Biol. Res. 2007, 150, 565-574. [CrossRef]

62. Holm, E.R. Barnacles and Biofouling. Integr. Comp. Biol. 2012, 52, 348-355. [CrossRef] [PubMed]

63. Wendt, D.; Kowalke, G.; Kim, J.; Singer, I. Factors that influence elastomeric coating performance: The effect of coating thickness on basal plate morphology, growth and critical removal stress of the barnacle Balanus amphitrite. Biofouling 2006, 22, 1-9. [CrossRef]

64. Larsson, A.I.; Mattsson-Thorngren, L.; Granhag, L.M.; Berglin, M. Fouling-release of barnacles from a boat hull with comparison to laboratory data of attachment strength. J. Exp. Mar. Biol. Ecol. 2010, 392, 107-114. [CrossRef]

65. Southward, A. Barnacles: Keys and Notes for the Identification of British Species; Field Studies Council: Shrewsbury, UK, 2008; Volume 57, p. 140.

66. Khandeparker, L.; Anil, A.C. Underwater adhesion: The barnacle way. Int. J. Adhes. Adhes. 2007, 27, 165-172. [CrossRef]

67. Essock-Burns, T.; Gohad, N.V.; Orihuela, B.; Mount, A.S.; Spillmann, C.M.; Wahl, K.J.; Rittschof, D. Barnacle biology before, during and after settlement and metamorphosis: A study of the interface. J. Exp. Biol. 2017, 220, 194-207. [CrossRef]

68. Anil, A.C.; Desai, D.; Khandeparker, L. Larval development and metamorphosis in Balanus amphitrite Darwin (Cirripedia; Thoracica): Significance of food concentration, temperature and nucleic acids. J. Exp. Mar. Biol. Ecol. 2001, 263, 125-141. [CrossRef]

69. Crisp, D.J.; Spencer, C. The control of the hatching process in barnacles. Proc. R. Soc. B Biol. Sci. 1958, 149, 278-299.

70. Clare, A.S.; Matsumura, K. Nature and perception of barnacle settlement pheromones. Biofouling 2000, 15, 57-71. [CrossRef]

71. Abramova, A.; Lind, U.; Blomberg, A.; Rosenblad, M.A. The complex barnacle perfume: Identification of waterborne pheromone homologues in Balanus improvisus and their differential expression during settlement. Biofouling 2019, 35, 416-428. [CrossRef] [PubMed]

72. Hadfield, M.G. Biofilms and Marine Invertebrate Larvae: What Bacteria Produce That Larvae Use to Choose Settlement Sites. Annu. Rev. Mar. Sci. 2011, 3, 453-470. [CrossRef] [PubMed]

73. Holmström, C.; Rittschof, D.; Kjelleberg, S. Inhibition of Settlement by Larvae of Balanus amphitrite and Ciona intestinalis by a Surface-Colonizing Marine Bacterium. Appl. Environ. Microbiol. 1992, 58, 2111-2115. [CrossRef] [PubMed]

74. Dickinson, G.H.; Vega, I.E.; Wahl, K.J.; Orihuela, B.; Beyley, V.; Rodriguez, E.N.; Everett, R.K.; Bonaventura, J.; Rittschof, D. Barnacle cement: A polymerization model based on evolutionary concepts. J. Exp. Biol. 2009, 212, 3499-3510. [CrossRef]

75. Ten Hove, H.; Kupriyanova, E. Taxonomy of Serpulidae (Annelida, Polychaeta): The state of affairs. Zootaxa 2009, 2036, 1-126. [CrossRef] 
76. Kupriyanova, E.; Nishi, E.; Hove, H.; Rzhavsky, A. Life-history patterns in serpulimorph polychaetes: Ecological and Evolutionary perspectives. Oceanogr. Mar. Biol. 2001, 39, 1-101.

77. Toonen, R.J.; Pawlik, J.R. Settlement of the tube worm Hydroides dianthus (Polychaeta: Serpulidae): Cues for gregarious settlement. Mar. Biol. 1996, 126, 725-733. [CrossRef]

78. Bruno, P. Escape Hatches for the Clonal Offspring of Serpulid Polychaetes. Biol. Bull. 2001, 200, 107-117.

79. Jusoh, I.; Wolfram, J. Effects of marine growth and hydrodynamic loading on offshore structures. J. Mek. 1996, 1, 77-96.

80. Decurey, B.; Schoefs, F.; Barillé, A.L.; Soulard, T. Model of Bio-Colonisation on Mooring Lines: Updating Strategy Based on a Static Qualifying Sea State for Floating Wind Turbines. J. Mar. Sci. Eng. 2020, 8, 108. [CrossRef]

81. Relini, G.; Tixi, F.; Relini, M.; Torchia, G. The macrofouling on offshore platforms at Ravenna. Int. Biodeterior. Biodegrad. 1998, 41, 41-55. [CrossRef]

82. Miller, R.; Macleod, A. Marine Growth Mapping and Monitoring: Feasibility of Predictive Mapping of Marine Growth; Shree Rajasthan Syntex Ltd.: Glasgow, UK, 2016; p. 51.

83. Oliveira, D.; Granhag, L. Matching Forces Applied in Underwater Hull Cleaning with Adhesion Strength of Marine Organisms. J. Mar. Sci. Eng. 2016, 4, 66. [CrossRef]

84. Schultz, M.P.; Kavanagh, C.J.; Swain, G.W. Hydrodynamic forces on barnacles: Implications on detachment from fouling-release surfaces. Biofouling 1999, 13, 323-335. [CrossRef]

85. Holm, E.R.; Kavanagh, C.J.; Meyer, A.E.; Wiebe, D.; Nedved, B.T.; Wendt, D.; Smith, C.M.; Hadfield, M.G.; Swain, G.; Wood, C.D.; et al. Interspecific variation in patterns of adhesion of marine fouling to silicone surfaces. Biofouling 2006, 22, 233-243. [CrossRef] [PubMed]

86. Callaghan, J.; Boud, R. Future Marine Energy. Results of the Marine Energy Challenge: Cost Competitiveness and Growth of Wave and Tidal Stream Energy; Carbon Trust: London, UK, 2006; pp. 1-36.

87. Mérigaud, A.; Ringwood, J.V. Condition-based maintenance methods for marine renewable energy. Renew. Sustain. Energy Rev. 2016, 66, 53-78. [CrossRef]

88. Borthwick, A.G.L. Marine Renewable Energy Seascape. Engineering 2016, 2, 69-78. [CrossRef]

89. Dobretsov, S.; Coutinho, R.; Rittschof, D.; Salta, M.; Ragazzola, F.; Hellio, C. The oceans are changing: Impact of ocean warming and acidification on biofouling communities. Biofouling 2019, 35, 585-595. [CrossRef]

90. Redfield, A.; Ketchum, B. Marine Fouling and Its Prevention; United States Naval Institute: Annapolis, MD, USA, 1952; p. 388.

91. Fischer, E.; Castelli, V.; Rodgers, S.; Bleile, H. Technology for Control of Marine Biofouling-A Review. In Marine Biodeterioration: An Interdisciplinary Study; Costlaw, J.D., Tipper, R.C., Eds.; Naval Institute Press: Annapolis, MD, USA, 1984; pp. 261-299.

92. Swain, G. Redefining antifouling coatings. J. Prot. Coat. Linings 1999, 16, 26-35.

93. Chambers, L.D.; Stokes, K.R.; Walsh, F.C.; Wood, R.J. Modern Approaches to Marine Antifouling Coatings. Surf. Coat. Technol. 2006, 201, 3642-3652. [CrossRef]

94. Fusetani, N.; Clare, A. Antifouling Compounds; Springer: Berlin/Heidelberg, Germany, 2006; p. 226.

95. Almeida, E.; Diamantino, T.C.; De Sousa, O. Marine paints: The particular case of antifouling paints. Prog. Org. Coat. 2007, 59, 2-20. [CrossRef]

96. Magin, C.M.; Cooper, S.P.; Brennan, A.B. Non-toxic antifouling strategies. Mater. Today 2010, 13, 36-44. [CrossRef]

97. Salta, M.; Wharton, J.A.; Stoodley, P.; Dennington, S.P.; Goodes, L.R.; Werwinski, S.; Mart, U.; Wood, R.J.K.; Stokes, K.R. Designing biomimetic antifouling surfaces. Philos. Trans. R. Soc. A Math. Phys. Eng. Sci. 2010, 368, 4729-4754. [CrossRef] [PubMed]

98. Callow, J.A.; Callow, M.E. Trends in the development of environmentally friendly fouling-resistant marine coatings. Nat. Commun. 2011, 2, 1-10. [CrossRef] [PubMed]

99. Dafforn, K.A.; Lewis, J.A.; Johnston, E.L. Antifouling strategies: History and regulation, ecological impacts and mitigation. Mar. Poll. Bull. 2011, 62, 453-465. [CrossRef]

100. Buskens, P.; Wouters, M.; Rentrop, C.; Vroon, Z. A brief review of environmentally benign antifouling and foul-release coatings for marine applications. J. Coat. Technol. Res. 2013, 10, 29-36. [CrossRef]

101. Gittens, J.E.; Smith, T.J.; Suleiman, R.; Akid, R. Current and emerging environmentally-friendly systems for fouling control in the marine environment. Biotechnol. Adv. 2013, 31, 1738-1753. [CrossRef] 
102. Legg, M.; Yücel, M.K.; Garcia de Carellan, I.; Kappatos, V.; Selcuk, C.; Gan, T.H. Acoustic methods for biofouling control: A review. Ocean Eng. 2015, 103, 237-247. [CrossRef]

103. Ciriminna, R.; Bright, F.V.; Pagliaro, M. Ecofriendly Antifouling Marine Coatings. ACS Sustain. Chem. Eng. 2015, 3, 559-565. [CrossRef]

104. Amara, I.; Miled, W.; Slama, R.B.; Ladhari, N. Antifouling processes and toxicity effects of antifouling paints on marine environment. A review. Environ. Toxicol. Pharmacol. 2018, 57, 115-130. [CrossRef]

105. Xie, Q.; Pan, J.; Ma, C.; Zhang, G. Dynamic surface antifouling: Mechanism and systems. Soft Matter 2019, 15, 1087-1107. [CrossRef]

106. Verma, S.; Mohanty, S.; Nayak, S. A review on protective polymeric coatings for marine applications. J. Coat. Technol. Res. 2019, 16, 307-338. [CrossRef]

107. Owusu, P.A.; Asumadu-Sarkodie, S. A review of renewable energy sources, sustainability issues and climate change mitigation. Cogent Eng. 2016, 3, 1167990. [CrossRef]

108. Hunsucker, K.Z.; Braga, C.; Gardner, H.; Jongerius, M.; Hietbrink, R.; Salters, B.; Swain, G. Using ultraviolet light for improved antifouling performance on ship hull coatings. Biofouling 2019, 35, 658-668. [CrossRef] [PubMed]

109. Wake, H.; Takahashi, H.; Takimoto, T.; Takayanagi, H.; Ozawa, K.; Kadoi, H.; Okochi, M.; Matsunaga, T. Development of an electrochemical antifouling system for seawater cooling pipelines of power plants using titanium. Biotechnol. Bioeng. 2006, 95, 468-473. [CrossRef] [PubMed]

110. Dickenson, N.C.; Krumholz, J.S.; Hunsucker, K.Z.; Radicone, M. Iodine-infused aeration for hull fouling prevention: A vessel-scale study. Biofouling 2017, 33, 955-969. [CrossRef]

111. Gunari, N.; Brewer, L.H.; Bennett, S.M.; Sokolova, A.; Kraut, N.D.; Finlay, J.A.; Meyer, A.E.; Walker, G.C.; Wendt, D.E.; Callow, M.E. The control of marine biofouling on xerogel surfaces with nanometer-scale topography. Biofouling 2011, 27, 137-149. [CrossRef]

112. Kirschner, C.M.; Brennan, A.B. Bio-inspired antifouling strategies. Annu. Rev. Mater. Res. 2012, 42, $211-229$. [CrossRef]

113. Hanssen, K.Ø.; Cervin, G.; Trepos, R.; Petitbois, J.; Haug, T.; Hansen, E.; Andersen, J.H.; Pavia, H.; Hellio, C.; Svenson, J. The bromotyrosine derivative ianthelline isolated from the arctic marine sponge Stryphnus fortis inhibits marine micro-and macrobiofouling. Mar. Biotechnol. 2014, 16, 684-694. [CrossRef] [PubMed]

114. Moodie, L.W.; Trepos, R.; Cervin, G.; Brathen, K.A.; Lindgard, B.; Reiersen, R.; Cahill, P.; Pavia, H.; Hellio, C.; Svenson, J. Prevention of marine biofouling using the natural allelopathic compound batatasin-III and synthetic analogues. J. Nat. Prod. 2017, 80, 2001-2011. [CrossRef]

115. Moodie, L.W.; Trepos, R.; Cervin, G.; Larsen, L.; Larsen, D.S.; Pavia, H.; Hellio, C.; Cahill, P.; Svenson, J. Probing the structure-activity relationship of the natural antifouling agent polygodial against both micro-and macrofoulers by semisynthetic modification. J. Nat. Prod. 2017, 80, 515-525. [CrossRef]

116. Moodie, L.W.; Cervin, G.; Trepos, R.; Labriere, C.; Hellio, C.; Pavia, H.; Svenson, J. Design and biological evaluation of antifouling dihydrostilbene oxime hybrids. Mar. Biotechnol. 2018, 20, 257-267. [CrossRef] [PubMed]

117. Bixler, G.D.; Theiss, A.; Bhushan, B.; Lee, S.C. Anti-fouling properties of microstructured surfaces bio-inspired by rice leaves and butterfly wings. J. Coll. Interface Sci. 2014, 419, 114-133. [CrossRef] [PubMed]

118. Dundar Arisoy, F.; Kolewe, K.W.; Homyak, B.; Kurtz, I.S.; Schiffman, J.D.; Watkins, J.J. Bioinspired photocatalytic shark-skin surfaces with antibacterial and antifouling activity via nanoimprint lithography. ACS Appl. Mater. Interfaces 2018, 10, 20055-20063. [CrossRef]

119. Trepos, R.; Cervin, G.; Hellio, C.; Pavia, H.; Stensen, W.; Stensvag, K.; Svendsen, J.S.; Haug, T.; Svenson, J. Antifouling compounds from the sub-arctic ascidian Synoicum pulmonaria: Synoxazolidinones A and C, pulmonarins A and B, and synthetic analogues. J. Nat. Prod. 2014, 77, 2105-2113. [CrossRef] [PubMed]

120. Trepos, R.; Cervin, G.; Pile, C.; Pavia, H.; Hellio, C.; Svenson, J. Evaluation of cationic micropeptides derived from the innate immune system as inhibitors of marine biofouling. Biofouling 2015, 31, 393-403. [CrossRef]

121. Trepos, R.; Pinori, E.; Jonsson, P.; Berglin, M.; Svenson, J.; Coutinho, R.; Lausmaa, J.; Hellio, C. Innovative approaches for the development of new copper-free marine antifouling paints. J. Ship Ocean Technol. 2014, 9, 7-18.

122. Inger, R.; Attrill, M.J.; Bearhop, S.; Broderick, A.C.; James Grecian, W.; Hodgson, D.J.; Mills, C.; Sheehan, E.; Votier, S.C.; Witt, M.J.; et al. Marine renewable energy: Potential benefits to biodiversity? An urgent call for research. J. Appl. Ecol. 2009, 46, 1145-1153. [CrossRef] 
123. Wilhelmsson, D.; Malm, T. Fouling assemblages on offshore wind power plants and adjacent substrata. Estuar. Coast. Shelf Sci. 2008, 79, 459-466. [CrossRef]

124. Langhamer, O.; Wilhelmsson, D.; Engström, J. Artificial reef effect and fouling impacts on offshore wave power foundations and buoys-A pilot study. Estuar. Coast. Shelf Sci. 2009, 82, 426-432. [CrossRef]

125. Lewis, J.; Coutts, A. Biofouling invasions. In Biofouling; Dürr, S., Thomason, J., Eds.; Wiley-Blackwell: Singapore, 2009; pp. 348-365.

126. Mineur, F.; Cook, E.J.; Minchin, D.; Bohn, K.; MacLeod, A.; Maggs, C.A. Changing coasts: Marine aliens and artificial structures. In Oceanography and Marine Biology-An Annual Review; Gibson, R.N., Atkinson, R.J.A., Gordon, J.D.M., Hughes, R.N., Eds.; CRC Press: Abingdon, UK, 2012; pp. 189-234.

127. Spalding, M.D.; Fox, H.E.; Allen, G.R.; Davidson, N.; Ferdaña, Z.A.; Finlayson, M.; Halpern, B.S.; Jorge, M.A.; Lombana, A.; Lourie, S.A.; et al. Marine Ecoregions of the World: A Bioregionalization of Coastal and Shelf Areas. BioScience 2007, 57, 573-583. [CrossRef]

128. Want, A.; Porter, J. BioFREE: An International Study of Biofouling Impacts on the Marine Renewable Energy Industry. In Proceedings of the 2018 OCEANS MTS/IEEE Kobe Techno-Oceans, Kobe, Japan, 28-31 May 2018; pp. 1874-1880.

(C) 2020 by the authors. Licensee MDPI, Basel, Switzerland. This article is an open access article distributed under the terms and conditions of the Creative Commons Attribution (CC BY) license (http://creativecommons.org/licenses/by/4.0/). 